\title{
Renewable Energy Generation Gaps in Poland: The Role of Regional Innovation Systems and Knowledge Transfer
}

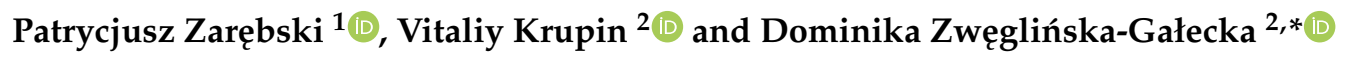 \\ 1 Department of Economics, Koszalin University of Technology, Kwiatkowskiego 6E, 75-343 Koszalin, Poland; \\ patrycjusz.zarebski@tu.koszalin.pl \\ 2 Institute of Rural and Agricultural Development, Polish Academy of Sciences, Nowy Świat 72, \\ 00-330 Warsaw, Poland; vkrupin@irwirpan.waw.pl \\ * Correspondence: dzweglinska@irwirpan.waw.pl
}

check for updates

Citation: Zarębski, P.; Krupin, V.; Zwęglińska-Gałecka, D. Renewable Energy Generation Gaps in Poland: The Role of Regional Innovation Systems and Knowledge Transfer Energies 2021, 14, 2935. https:// doi.org/10.3390/en14102935

Academic Editor: Gianfranco Chicco

Received: 30 April 2021

Accepted: 16 May 2021

Published: 19 May 2021

Publisher's Note: MDPI stays neutral with regard to jurisdictional claims in published maps and institutional affiliations.

Copyright: (c) 2021 by the authors. Licensee MDPI, Basel, Switzerland. This article is an open access article distributed under the terms and conditions of the Creative Commons Attribution (CC BY) license (https:// creativecommons.org/licenses/by/ $4.0 /)$.

\begin{abstract}
Aim of the research is to analyze regional gaps in terms of renewable energy generation across Poland. For this purpose, four types of regions were outlined based on two indicators: the existing renewable energy generation capacity and the current regional energy demand revealed through the number of residents. This classification allowed to reveal regions in Poland that have distinct features of energy gaps and peripherality, while also more successful regions with renewable energy surpluses and distinct sustainable energy potential. For each of the region type key potential systemic problems in terms of renewable energy generation development were given. To understand how peripheral regions and regions with energy gaps could be supported in their development of renewable energy generation the regional innovation systems, social networks, knowledge and technology transfer and diffusion were substantiated. Results of the research can serve as an aid in development of national and regional energy policies, helping to understand peculiarities of local renewable energy generation and the influence of enabling environment peculiar to the specific region, including the regional innovation systems and intensity of knowledge transfer and diffusion.
\end{abstract}

Keywords: renewable energy; energy policy; regional innovation system; social network; knowledge transfer

\section{Introduction}

Renewable sources of energy are among key sustainable development elements that are perceived as the future of our planet and can help in its environmental protection while satisfying the energy needs of global society. Due to the progressive economic development and the growth of the world's population the supplies of various fossil fuels necessary for energy generation are rapidly declining. Yet what is as important-the impact of energy generation from fossil fuels is polluting the environment and causing an intensifying climate change, thus leading to unpredictable consequences and shifts in various areas: weather events, climate zoning, plant growth patterns and biodiversity [1-3], and last but not least-human health [4]. These issues and the fact that their cause is mainly anthropogenic [5-7] is the reason numerous state governments and international organizations are taking actions to intensify shifting the societies and their economies toward sustainable development patterns and thus reducing or even stopping the unfavorable environmental and economic trends.

The European Union is especially active in this sense implementing policies aiming at large-scale transformations toward renewable energy generation, reduction of greenhouse gas emissions, and limiting the pollution of the environment. EU's Climate and Energy Framework [8] is one of such policies setting 2030 as their target year. Its basis is the recast Renewable Energy Directive (RED II) [9] with its key joint EU goals being: (a) at least 32\% share for renewable energy, (b) at least 32.5\% improvement in energy efficiency, and (c) $40 \%$ cuts in greenhouse gas emissions (compared to 1990 levels). 
To reach the joint renewable energy goal each EU country has set their 2030 targets within their National Energy and Climate Plans (NECP) [10], ranging from 10\% in Malta to $49 \%$ in Sweden, with an average 22\% share in the final consumption among all 27 states. Yet, due to the recent introduction of the European Green Deal these targets are to be updated, as in order to achieve the planned climate-neutrality by 2050 a reduction of the core indicator - the greenhouse gas emissions-needs to reach $55 \%$ by 2030 , thus requiring changes in the corresponding elements of the energy sector. In terms of the share of renewable energy in the final consumption the European Commission expects the target to increase from $32 \%$ to $38-40 \%$ at the EU-27 level [11].

Such ambitions will require intensified efforts from each EU member state, yet some of them are already struggling to reach the first stage levels-the ones set for the 2020 within the initial Renewable Energy Directive (RED I) and corresponding National Renewable Energy Action Plans. Our analysis of the current progress toward achieving the 2020 national renewable energy goals shows (Figure 1) that by the 2019 (more recent data is still not available [12]) nine countries were behind the schedule. The largest gaps were manifested by France (5.8 p.p.), the Netherlands (5.2 p.p.), Ireland (4 p.p.), and Luxembourg (4 p.p.). Among these countries is also Poland being 2.8 p.p. short of the 2020 goal, while the 2030 target of $21 \%$ of renewables in the final energy consumption implies the need of additional 6 p.p. to reach it. Future updates due to the European Green Deal will increase this obligation further.

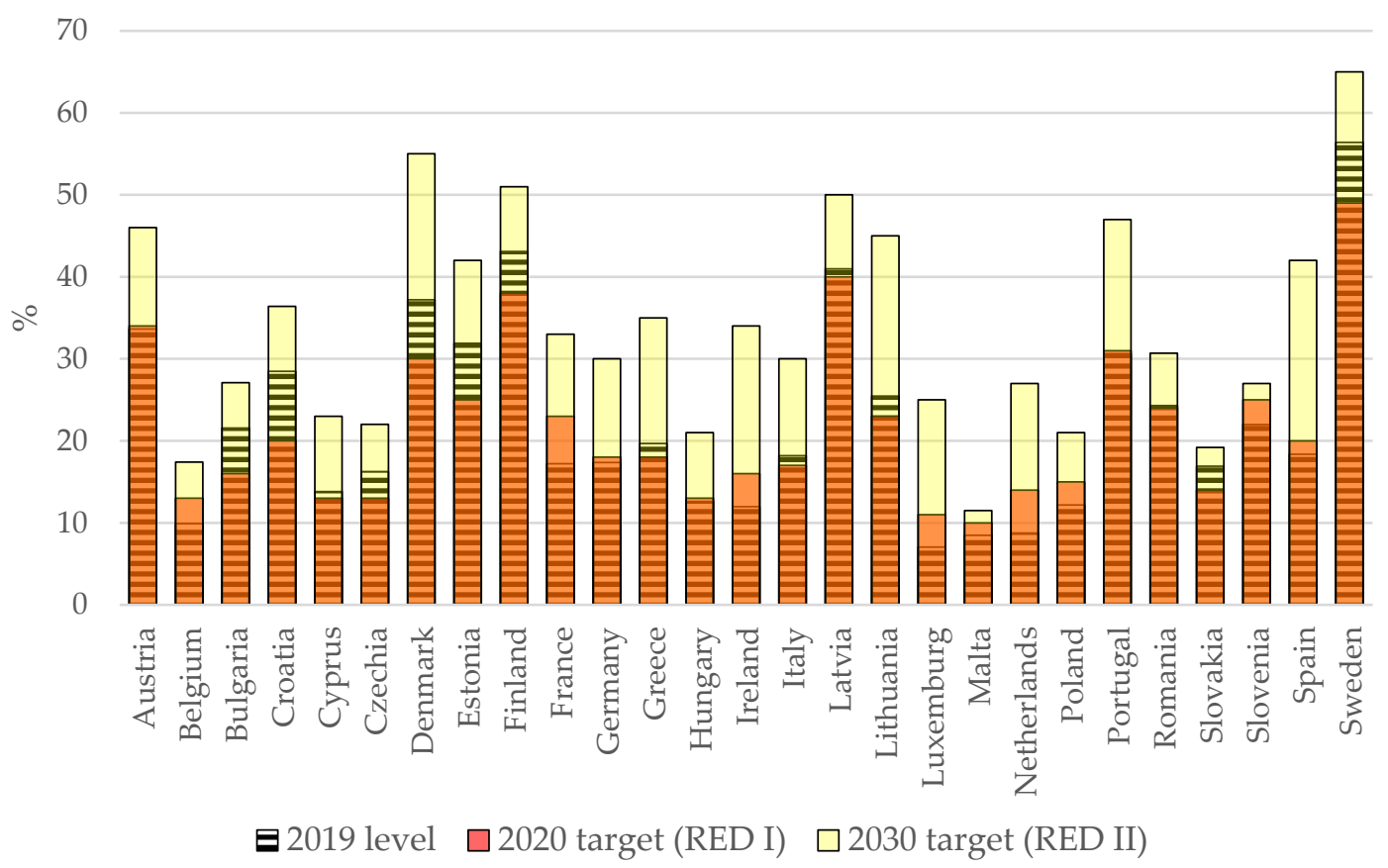

Figure 1. Actual (2019) and targeted (RED I by 2020 and RED II by 2030) shares of renewable energy in gross final energy consumption in the EU-27 countries. Source: own compilation based on $[10,12,13]$.

These expectations will require intensification of efforts from both Poland and other EU countries. Overall, the pace and efficiency of changes in the energy generation structure are determined by various economic factors related to the possibility of financing and conducting the modernization of energy infrastructure, both at the level of energy suppliers and consumers. However, apart from economic factors, non-economic factors of a social and organizational nature also deserve attention. This differentiation is further deepened by regional peculiarities and varying levels of socio-economic development, thus leading to forming of permanent leaders and outsiders among regions, thus deepening the differentiation further due to occurrence of a system archetype [14] called "success to the successful", having an adverse impact on peripheral regions. 
Therefore, the article aims to define the existing gaps in renewable energy generation across districts of Poland and to broaden the knowledge about the combined role of regional innovation systems, networks of enterprises and institutions in the process of knowledge and technology transfer and diffusion. It is put in the context of renewable energy generation development taking into account specific conditions of four outlined types of regions in regard to their energy generation capacities and further generation potential. The general theoretical framework is based on the theory of regional innovation systems [15,16], social networks [17] and the concept of "gatekeepers of knowledge" [18]. While this study is based on the case study of Poland, it helps to deliver new knowledge about the processes of renewable energy development typical for other countries as well, especially in the Central and Eastern Europe.

The need to intensify the further spread of technologies and their implementation in various regions arises not only from the necessity to increase the share of renewable energy generation to achieve the set targets. Decentralization of energy generation has also been emphasized upon by the RED II [9] stating that "the move towards decentralized energy production has many benefits, including the utilization of local energy sources, increased local security of energy supply, shorter transport distances and reduced energy transmission losses. Such decentralization also fosters community development and cohesion by providing income sources and creating jobs locally". It is also supporting the transformation toward ensuring of local and sustainable energy access [19], and minimizing possible energy access risks.

The conducted research revealed that in the diffusion of technologies and innovations in the field of renewable energy generation, the flow of knowledge and information is important, as it helps to raise awareness about the necessity of transformation toward renewable energy, as well as simplifies the access to innovational solutions and technologies. Such knowledge relates, inter alia, to the general characteristics of renewable energy sources, which are the resources obtained within natural processes that are not depleting limited natural supplies and are an alternative to conventional non-renewable energy sources. This knowledge is relatively well communicated and understandable to the majority. However, it can be difficult to understand the process of conversion between energy sources and how to engage the transformation in practice. As technologies and solutions constantly develop based on ongoing scientific research, there's a necessity to make this information more accessible and understandable. Currently, nine different sources of renewable energy are used in Poland, the main ones being the solid and liquid biofuels, as well as the wind energy (Figure 2). It is also worth mentioning that the structure of renewable energy generation in Poland is not yet highly diversified and differs significantly from the corresponding structure of the European Union.

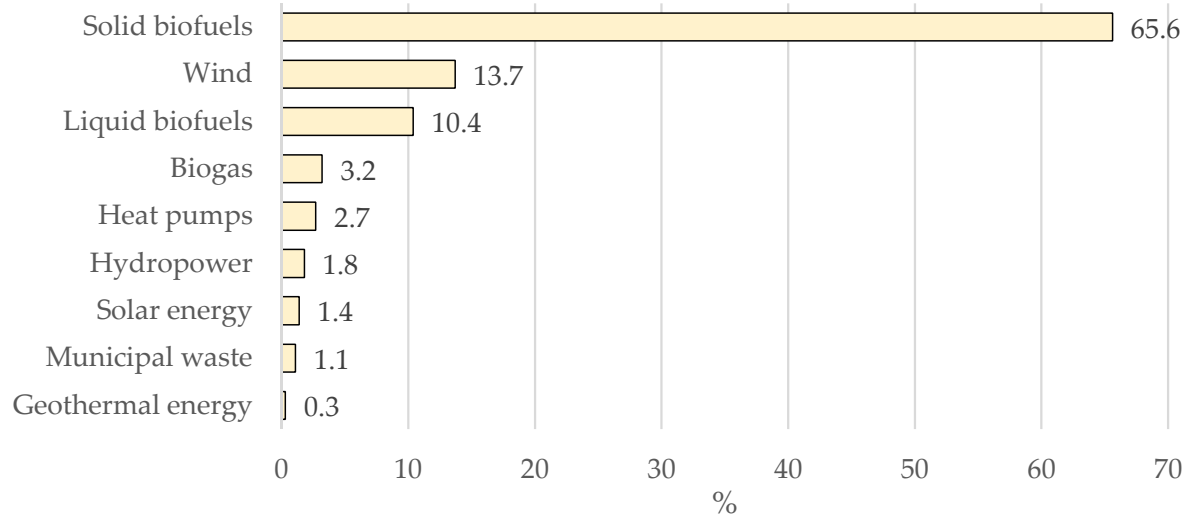

Figure 2. Structure of generated renewable energy by types of installations in Poland in 2019. Source: [20].

There are various factors causing the existing disproportions in the presented structure of renewable sources of energy. These include, among other, the state support and permit 
systems, investment costs, local conditions (e.g., territorial, infrastructural). Yet among other crucial factors are also knowledge level and rate of diffusion of innovations and technologies. When looking at regional level, the energy generation there takes place under specific conditions depending on particular region, which could be unbeneficial in case of unfavorable economic and social conditions. This is especially visible in case of peripheral areas, which are characterized by a number of negative phenomena caused by weak economic and social structure, low population density, low level of human capital, low infrastructural development, lack of available and adequate financing sources for implementation of new advanced technologies. Therefore, such areas require a separate approach in the context of renewable energy generation development. In the process of developing the energy innovations, apart from traditional factors related to the development of technologies and their financing, non-economic factors related to social relations and knowledge-flow networks are equally important. In the literature on the subject [21,22], the concept that has already gained a large group of supporters and constitutes the theoretical framework for the implementation of innovation and the flow of knowledge is the existence of regional innovation systems. So, what purpose can they serve in regard to renewable energy generation?

The knowledge and practical skills in the field of renewable energy generation are often developed and shared within limited scientific environments or enterprises involved in production of dedicated equipment. The knowledge gap arising from this fact is not the fault of these professional communities, yet is appearing due to technical limitations, complexity of issues and solutions, and lack of direct networking platforms involving stakeholders of various types. This knowledge gap is among the reasons why the rate of implementation of new technologies in the economy is too slow and falls behind the expected levels. Lack of knowledge about technologies and benefits, not only economic, but also environmental and social, is a significant barrier to sustainable development. Proper knowledge flow and its diffusion in various socio-economic environments can significantly accelerate development processes. One of the concepts that explains the mechanisms of creating and diffusing new technologies is one of the regional innovation system [23]. Its main underlying mechanism are the networks of relations within which their stakeholders exchange knowledge and cooperate in various projects. This concept embraces a multi-disciplinary approach, enabling to understand not only the role of technology in energy generation, but also social and policy conditions that are necessary to boost the processes of its implementation, especially the knowledge diffusion based on social networks and relations.

The emphasis on the importance of intensification of renewable energy generation results from a paradigm shift from the classic perception of energy policy [24] to its perception in terms of sustainable development. While concentrating the following analysis on the energy policy and its implications at local level, it is emphasized by the authors that this approach is not derived from the classic energy policy, but the so-called sustainable energy policy [25], being an overall long-term improvement of social welfare by striving to maintain a balance between the following: energy security, satisfaction of social needs, competitiveness of economy, and environmental protection. Thus, it is more than just ensuring the energy supply. There is a need to balance other crucial socio-economic elements, the condition and quality of which may significantly affect the conditions and the existing potential for development of renewable energy generation.

To conclude the introduction, the article consists of eight sections. Following the Introduction, Section 2 delivers information and literature review regarding peculiarities of renewable energy generation development in Central and Eastern EU countries. Section 3 explains the method used to carry out the analysis of regional renewable energy generation gaps in Poland, substantiates the use of own typology of regions according to their renewable energy generation potential, provides information about the data sources and peculiarities of approach in terms of regional dimension. Section 4 presents the research results, including: (a) an analysis of existing renewable energy generation capacities across 
districts of Poland aimed to understand the occurrence and scale of gaps at regional level, (b) an analysis of four outlined types of regions in regard to their renewable energy generation capacities, (c) recommendations for renewable energy development policy across the four outlined types of regions based on the influence of regional innovation systems and potential knowledge transfer. Section 5 covers the substantiation of regional innovation systems, social networks and knowledge transfer from the standpoint of stimulation of regional renewable energy generation in regions demonstrating energy peripherality and gaps, which is based on the literature review providing its synthesis and own arguments. Section 6 covers discussion between the obtained results and other studies, while the Section 7 is devoted to conclusions, implications of presented research and other possible research directions.

\section{Peculiarities of Renewable Energy Generation Development in Central and Eastern EU Countries}

Renewable energy sources (wind, solar, hydroelectric, ocean, geothermal, biomass and biofuels) are alternatives to fossil fuels and contribute to reducing greenhouse gas emissions, diversifying energy supply and reducing dependence on uncertain and unstable fossil fuel markets, especially oil and gas. Global development dynamics of energy generation from renewable sources in recent decades indicate that combined they are the fastest growing exploited source of energy. This is clearly visible in economies of such countries as USA, India or China. For example, the key slogan for current India's economic development is "Go Green", which is actively implemented through development of renewable energy generation, zero-emission public transport, other "green" technologies [26].

Yet while the development of renewable energy generation is becoming a global trend, there are differences between countries and macroregions due to specificities of socio-economic past and present development. The report "Global trends in renewable energy investment 2020" indicates that on a global scale, investments in the renewable energy sector in developed economies increased by $2 \%$ in 2019 only (compared to the previous year) - to USD 130 billion. At the same time, it is stressed that there were sharp increases in outlays in the USA, Spain, the Netherlands and Poland, and big falls in the UK, Germany, Australia and Belgium [27].

Renewable energy resources and the level of their utilization should be assessed primarily through the prism of a country's energy supply and demand. Consequently, the concept of a renewable energy resource is a purely economic concept and is derived from the function it delivers. And it should be remembered that the amount of renewable energy supply may increase according to the changes in the energy needs and along the growing knowledge and technological possibilities of its conversion into exploitable energy. Although on the EU-27 scale the share of renewable energy in gross final energy consumption has increased from $9.6 \%$ (2004) to $19.7 \%$ (2019) [12], it is precisely the above-mentioned aspects that can be indicated as the reasons why the "renewable energy revolution" [28] takes place at a different pace in different countries. The use of natural resources for energy generation depends on many factors that could be categorized collectively as: economic, social, legislative, and-to a lesser extent-technological [29]. Although renewable energy generation will definitely be one of key development elements of future long-term EU strategies, their implementation to an equal extent in all EU countries will always be a difficult task due to differences in national priorities and conditions. In Western Europe, the focus on decarbonisation, slowing the climate change and building a single energy market is well underway, while in countries of Central and Eastern EU, where large share of energy is still derived from conventional fuels, a rapid transformation replacing them with renewable energy sources will be more difficult.

The EU member states, in the name of the common good and to limit the climate change can support one energy source at the expense of abandoning other. Yet to implement such choices key factor is the social support. Therefore, an awareness of climate change challenges facing all economic sectors is an increasingly discussed issue among the academic circles and general public, which is the case in the European Union countries, and 
especially those in Central and Eastern Europe. Within these debates researchers emphasize the importance of natural, spatial [30], technological [31], social, and political [32,33] conditions for the development of renewable energy generation. Researchers indicate potentials for such generation and determine the possible development paths-both renewable energy generation in general and broken down into specific types of renewable energy sources, also taking into account the interrelationships between sources that can be used for generation of electricity, heat and transport fuels [34].

In the literature it is indicated that countries of Central and Eastern EU have substantial problems in steering the process of setting and achieving long-term energy policy goals due to the short-term way of thinking, characteristic for countries undergoing economic transformation [35]. Not without significance are the past experiences of communism common for the countries of Central and Eastern Europe, which still manifest specific impact on local development conditions, including relatively higher corruption, low trust in political elites and innovative solutions [36]. For example, in Poland, on one side, a strong political force is aiming to keep the traditional framework in the energy sector (e.g., large-scale generation, use of coal), and on the other side, there is an understanding of alternativeless need to intensify the shift to renewable energy generation, which is not only an important element of the global climate protection movement and part of EU policies, but is also cheaper, more efficient and increases local energy security. Yet it is indicated that level of participation of the public in creation of the energy policy is still not sufficient, which may cause the deficiency in development of the prosumer model of renewable energy generation [37]. These issues overall impact the support for renewable energy generation and implementation of policy measures aimed at such development, as well as cause implementation of support mechanisms to be highly volatile, thus making this sector relatively less attractive for investors and entrepreneurs. Existing barriers increase investment risks, which translate directly onto the costs of energy obtained from these sources, which could be higher compared to energy obtained from conventional energy sources. It is also indicated that renewable energy generation technologies are characterized by an uneven pace of energy supply over time or even intermittent operation process, meaning their generation level could be at times inconsistent with the level of energy demand. At the same time, researchers emphasize that the need to take action is forced both by international public obligations in the field of climate change mitigation adopted by all the EU countries (including the Central and Eastern ones), as well as economic, social and environmental considerations, which results in the necessity to undertake costly investments not only in the energy generation sector, but also in energy transmission infrastructure.

\section{Materials and Methods}

According to the legislation in Poland [38] a renewable energy generation installation is an installation that constitutes a separate set of devices used to generate energy, described by technical and commercial data, in which energy is produced from renewable energy sources, or construction facilities and equipment constituting a technical and utility unit used to generate agricultural biogas-as well as an energy storage connected to this unit, including an agricultural biogas storage facility.

While the sources of renewable energy vary, generated output can be converted into either electrical or thermal energy. This article, due to data limitations, deals strictly with generation of electrical energy, thus it is meant across the article whenever generation of energy is mentioned.

Processes of innovation and technology diffusion are conditioned by spatial factors and depend on peculiarities of local socio-economic systems. Due to this, an analysis of spatial allocation's differentiation regarding existing technological capacities for generation of energy from renewable sources was carried out in relation to the regional energy demand expressed by a number of people living in a given administrative area. Presented herewith study aims to understand the differences between the regions in development 
of renewable energy generation capacities and define what mechanisms determined this process. Description of the research stages adopted for this study can be found in Figure 3. First, a literature review was carried out to explore the renewable energy generation specificities across Poland and define what factors could influence decisions to undertake the development of such generation capacities. In the next stage (the empirical part), a spatial analysis of allocation of renewable energy generation capacities was carried out. It was conducted based on indicators assigned to individual districts in accordance with the "Jenks natural breaks optimization" method [39] and presented on maps. This method is used to present heterogeneous data sets as it aggregates analytical units into groups with similar values. Grouping of values in different classes is carried out by the function aiming to minimize the mean deviation of each class from the mean class, while maximizing the deviation of each class from the mean of other groups. The next step was to develop a typology of regions based on the relationship of the two aforementioned datasets. The first one represented the aggregate index of technological capacity, while the second one represented the population quantity in a given area. Understanding the occurrence of districts manifesting energy gaps and energy peripherality was the basis to go deeper into research of regional innovation systems (RIS) and their possible influence upon intensification of renewable energy generation development. The regional innovation systems therefore, constitute the theoretical framework for considerations and explain such phenomena as social embedding of innovation processes and institutional relations, which play an important role in knowledge and technology transfer processes.

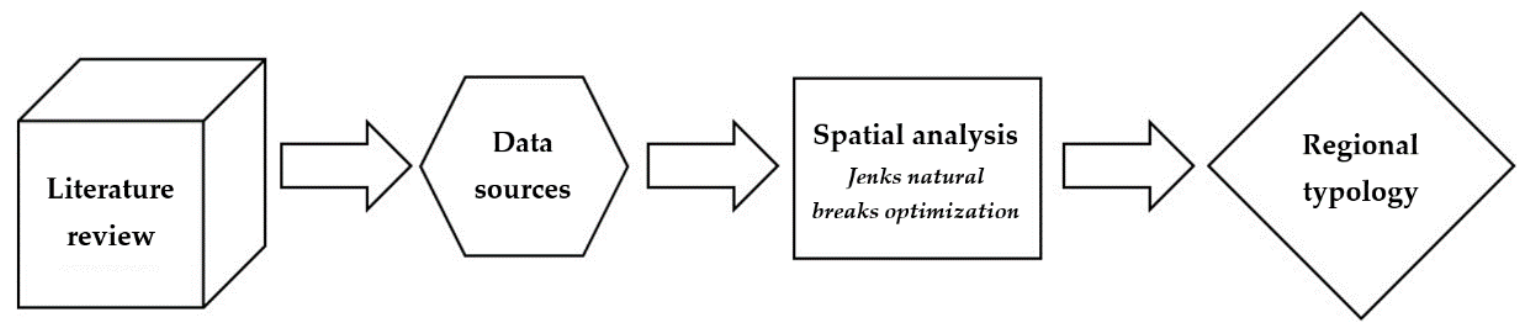

Figure 3. Algorithm of the performed research. Source: own substantiation with the use of [39].

In terms of the covered types of renewable energy sources (RES), a region's relative renewable energy generation potential depends mainly on the capacity of generation installations based on renewable energy sources in relation to the energy demand expressed by number of residents in a given region. Large disproportions in this relation cause regional energy surpluses or deficits (energy gaps), meaning in some regions an imbalance between supply and demand for energy is present. In order to better recognize this phenomenon, statistical data was collected about the regional capacities of installations aimed for renewable energy generation, utilizing the following:

- $\operatorname{Biogas}(\mathrm{BG})$,

- Biomass (BM),

- Solar energy (PVA),

- Wind energy (WIL),

- Hydropower (WO),

- Technology of co-combustion of biomass, biogas or bioliquids combined with other fuels (fossil fuels and biomass/biogas/bioliquids) (ITPO).

Therefore, the aggregate energy generation capacity from renewable sources (EGC) is calculated as the total of generation capacities of all available technologies:

$$
B G_{i}+B M_{i}+P V A_{i}+W I L_{i}+W O_{i}+I T P O_{i}=E G C_{i}
$$

where:

$i$-spatial unit number, 
EGC - energy generation capacities from all renewable sources.

Due to existence of diversified technologies for electricity generation the data on different types of renewable energy installations is derived from various sources and covers those entities and individuals which have: a license to generate electricity, an entry in the regulated activity register kept by the President of the Energy Regulatory Office [40] (register of small installation energy producers [41]), an entry in the regulated activity register kept by the General Director of the National Agricultural Support Center [42] (register of agricultural biogas producers [43]), as well as micro-installations generating electricity under the "certificate of origin" system, the guaranteed feed-in tariff system, or the auction support system [44]. The main source of data used within the study were those published by the Central Statistical Office in Poland (GUS), additionally some of the data was obtained from available statistical and scientific publications.

The regional renewable energy generation capacities are presented in the study at a district level, which in Poland are referred to as powiat, being units of the second-degree state administrative division, each consisting of several municipalities (gmina) and having its own administrative body. The total number of such districts in Poland equals 314.

In the scientific literature it is said that deficits and problems in the functioning of regional innovation systems can be related to the conditions that prevail in specific types of regions, such as peripheral regions (facing organizational thinness), old industrial areas (facing cognitive blockades) and some metropolitan regions (facing fragmentation of interactions and networks) [45]. It should be noted that in many cases the problems of regional innovation development are in fact similar, but there may be some dominant innovation problems specific to a given type of region. Therefore, the authors propose four types of regions that differ in terms of population numbers and renewable energy generation capacities.

In the Figure 4 , the $X$-axis holds two types of population quantity expressed through the number of inhabitants and the $Y$-axis represents the renewable energy generation capacity. The four quarters are constructed on the basis of the average results of assessments of these two parameters. The average number of inhabitants for the collected data across the regions equaled 82,185 people, while the average renewable energy generation capacity was at the level of $28.5 \mathrm{MW}$. These values are the cut-off points that determine the energy region types.

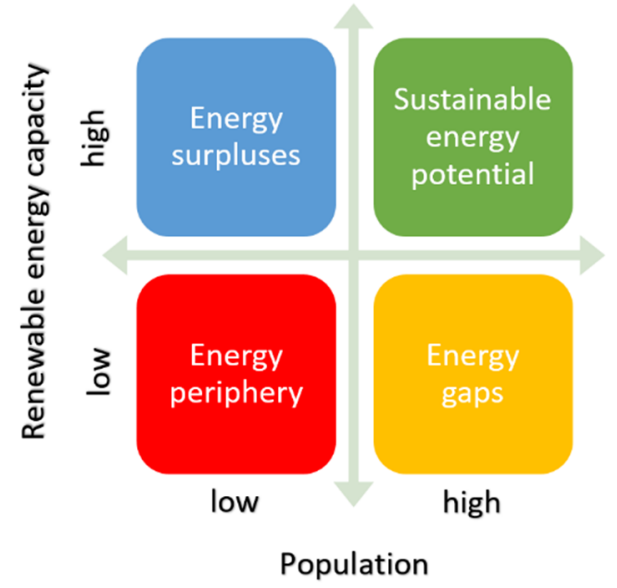

Figure 4. Outlined region types according to the energy/population parameters. Source: own substantiation.

The research questions to be explored within the article include:

- What disproportions occur between regions concerning renewable energy generation, which regions can be considered peripheral in this regard and which manifest existence of technological gaps? 
- What systemic problems block the development of renewable energy generation technologies region-wise?

- Can regional innovation systems support and intensify the innovation and technology deployment process in regions with energy deficits and regions with peripheral features?

- What is the role of social and organizational networks in the policy of innovation and technology knowledge diffusion in regard to renewable energy generation?

\section{Defining the Renewable Energy Generation Gaps at Regional Level}

Determining the capacity of renewable energy generation installations and the population quantity in districts allowed to develop spatial distribution of energy generation from available renewable sources across Poland. Results (Table 1) revealed that overall energy generation from renewable energy installations within the 2005-2020 increased over ninefold. The quantity and capacity of solar energy installations have shown the most dynamic growth rates. State support programs and subsidies encouraging to invest in such installations are a key driver [46] and a clear long-term state policy toward development of renewable energy generation sources is of high importance [29].

Table 1. Dynamics of installed renewable energy generation capacities within 2005-2020 in Poland [in MW].

\begin{tabular}{lcccc}
\hline \multirow{2}{*}{ Types of Installations } & \multicolumn{4}{c}{ Years } \\
\cline { 2 - 5 } & $\mathbf{2 0 0 5}$ & $\mathbf{2 0 1 0}$ & $\mathbf{2 0 1 5}$ & $\mathbf{2 0 2 0}$ \\
\hline Biogas & 31.972 & 82.884 & 212.497 & 255.699 \\
\hline Biomass & 189.790 & 356.190 & 1122.670 & 1512.885 \\
\hline Solar energy & - & 0.033 & 71.031 & 887.434 \\
\hline Wind energy & 83.280 & 1180.272 & 4582.036 & 6347.111 \\
\hline Hydropower & 852.495 & 937.044 & 981.799 & 976.047 \\
\hline Total & 1157.537 & 2556.423 & 6970.033 & 9979.176 \\
\hline
\end{tabular}

Source: Energy Regulatory Office in Poland.

In-depth analysis of the collected data split by the types of renewable energy generation installations in Poland is presented in Table 2, while Figure 5 presents their density distributions.

Table 2. Descriptive statistics for the analysis of renewable energy generation installations in Poland.

\begin{tabular}{|c|c|c|c|c|c|c|c|}
\hline \multirow[b]{2}{*}{ Parameters } & \multicolumn{7}{|c|}{ Types of Installations } \\
\hline & Biogas & $\begin{array}{l}\text { Solar } \\
\text { Energy }\end{array}$ & $\begin{array}{l}\text { Wind } \\
\text { Energy }\end{array}$ & Hydropower & Biomass & $\begin{array}{c}\text { Co- } \\
\text { Combustion }\end{array}$ & $\begin{array}{c}\text { All } \\
\text { Sources }\end{array}$ \\
\hline Valid & 156 & 276 & 208 & 191 & 29 & 4 & 314 \\
\hline Missing & 158 & 38 & 106 & 123 & 285 & 310 & 0 \\
\hline Mean & 1.267 & 3.152 & 30.495 & 4.144 & 23.584 & 12.447 & 28.457 \\
\hline Std. Error of Mean & 0.091 & 0.226 & 4.037 & 1.332 & 10.228 & 2.170 & 3.033 \\
\hline Median & 1.000 & 2.015 & 10.915 & 0.220 & 2.200 & 11.400 & 9.450 \\
\hline Mode* & 1.000 & 1.000 & 0.600 & 0.030 & 0.050 & 8.990 & 1.000 \\
\hline Std. Deviation & 1.131 & 3.749 & 58.230 & 18.415 & 55.077 & 4.340 & 53.740 \\
\hline Variance & 1.278 & 14.055 & 3390.683 & 339.114 & 3033.454 & 18.833 & 2887.993 \\
\hline Skewness & 1.856 & 2.804 & 6.185 & 8.504 & 2.853 & 0.745 & 5.887 \\
\hline Std. Error of Skewness & 0.194 & 0.147 & 0.169 & 0.176 & 0.434 & 1.014 & 0.138 \\
\hline Kurtosis & 6.097 & 11.191 & 56.055 & 83.765 & 7.891 & -1.865 & 54.389 \\
\hline
\end{tabular}


Table 2. Cont.

\begin{tabular}{ccccccccc}
\hline \multirow{2}{*}{ Parameters } & Biogas & $\begin{array}{c}\text { Solar } \\
\text { Energy }\end{array}$ & $\begin{array}{c}\text { Wind } \\
\text { Energy }\end{array}$ & Hydropower & Biomass & $\begin{array}{c}\text { Co- } \\
\text { Combustion }\end{array}$ & $\begin{array}{c}\text { All } \\
\text { Sources }\end{array}$ \\
\cline { 2 - 8 } & 0.386 & 0.292 & 0.336 & 0.350 & 0.845 & 2.619 & 0.274 \\
\hline Std. Error of Kurtosis & 7.620 & 25.710 & 631.130 & 207.170 & 229.950 & 9.010 & 634.940 \\
\hline Range & 0.040 & 0.020 & 0.010 & 0.010 & 0.050 & 8.990 & 0.000 \\
\hline Minimum & 7.660 & 25.730 & 631.140 & 207.180 & 230.000 & 18.000 & 634.940 \\
\hline Maximum & 197.660 & 869.960 & 6342.970 & 791.410 & 683.950 & 49.790 & 8935.400 \\
\hline Sum & 0.378 & 0.935 & 2.000 & 0.080 & 0.950 & 8.998 & 3.020 \\
\hline 25th percentile & 1.000 & 2.015 & 10.915 & 0.220 & 2.200 & 11.400 & 9.450 \\
\hline 50th percentile & 1.903 & 4.190 & 42.045 & 1.125 & 5.800 & 14.850 & 30.230 \\
\hline 75th percentile & & & & &
\end{tabular}

Notes: * More than one mode exists, only the first is reported. Source: own calculations.
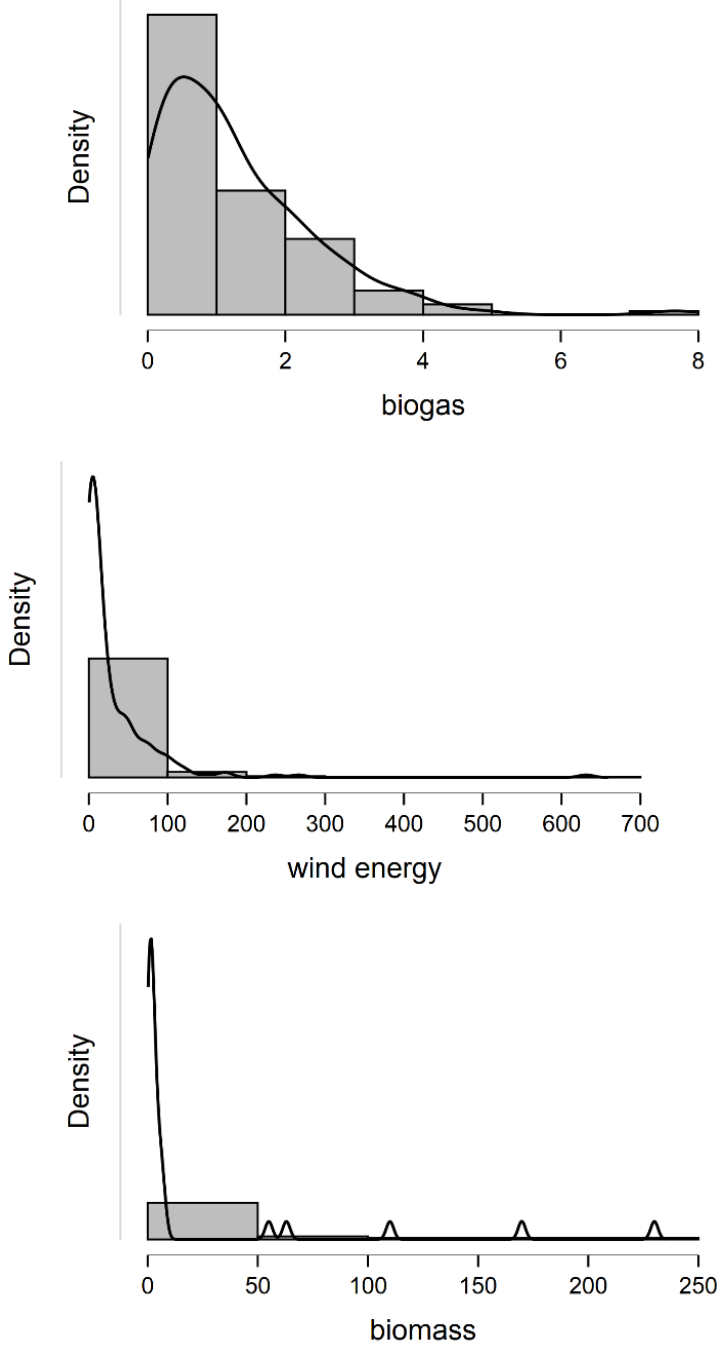
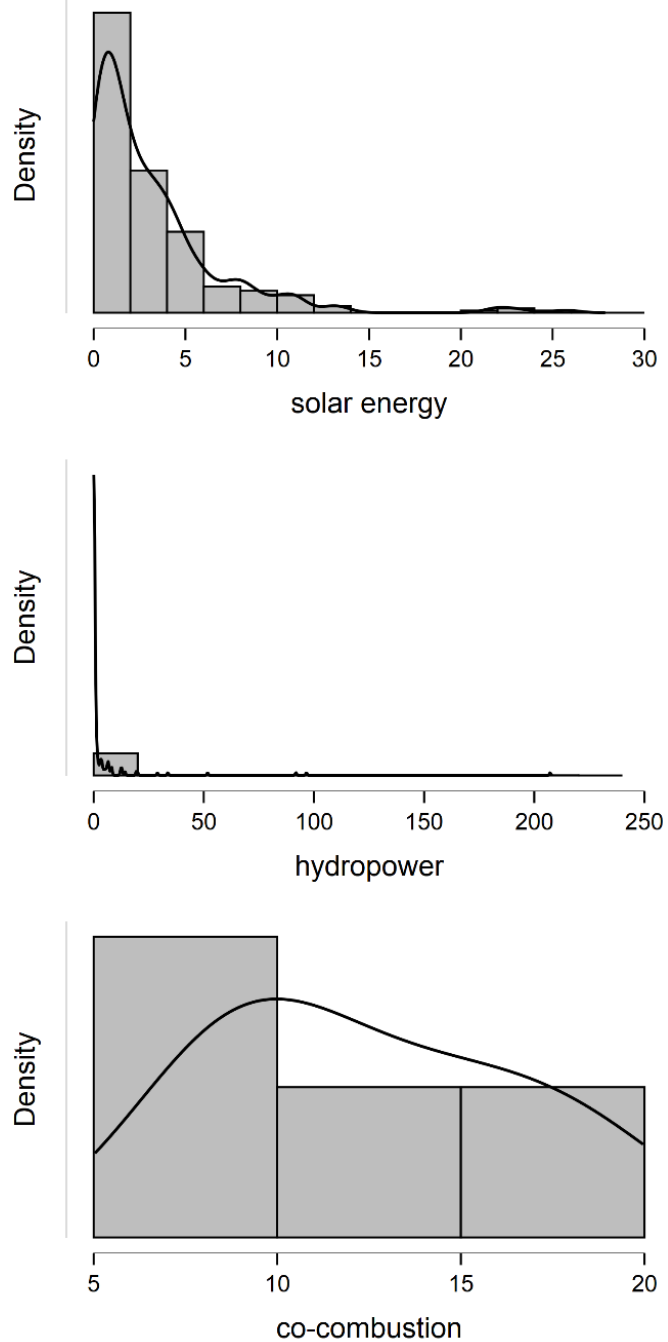

Figure 5. Density distribution of renewable energy generation installations in districts of Poland in 2020. Source: own calculations.

On the national scale in Poland, among the analyzed types of renewable energy generation capacities the highest density is present in case of installations for solar energy generation, which are located mainly in the north and east of the country (Figure 6). Districts located in the Pomorskie region (north-western part of the country, with access to 
the Baltic Sea coast) are national leaders in their construction. In turn, the areas of central

Poland are showing the lowest densities or even lacking such installations whatsoever.
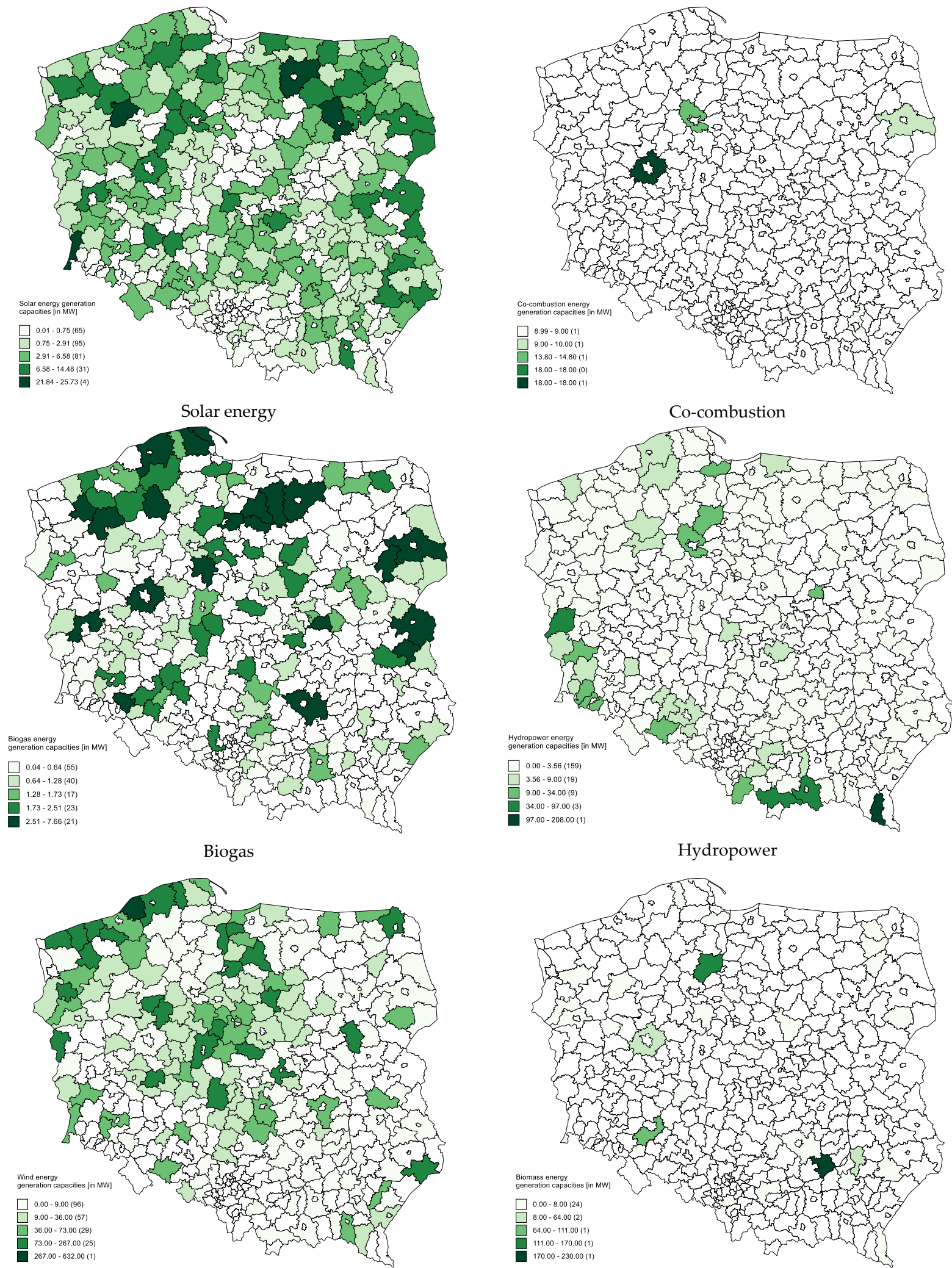

Wind energy

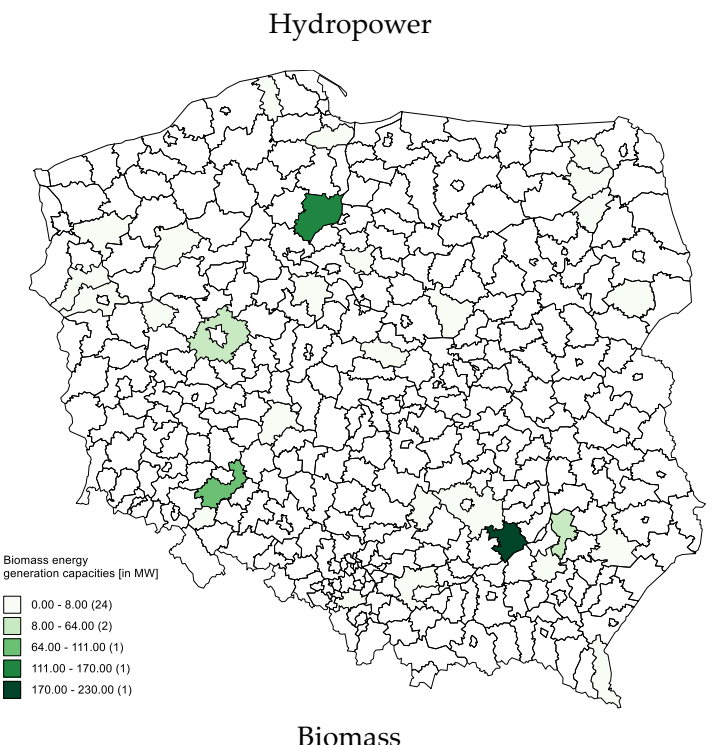

Figure 6. Renewable energy generation capacity by types of installations in districts of Poland in 2020. Source: own calculations and presentation. 
It should be noted that the renewable energy installations are overall scattered across the nation, and such approach is one of the pillars of state energy policy. The purpose of having decentralized energy sources is to provide energy supplies to less urbanized areas and rural areas, as well as to guarantee sustainable local development of those areas. The main reason for the development of decentralized energy sources is the technological progress, which contributes to the reduction of costs of energy generation from renewable sources, as well as the possibility to utilize energy resources available locally.

Figure 7 presents the combined data about renewable energy generation capacities for installations of all analyzed types, while also revealing the distribution of population among the districts, which served to proceed with typologization of regions.
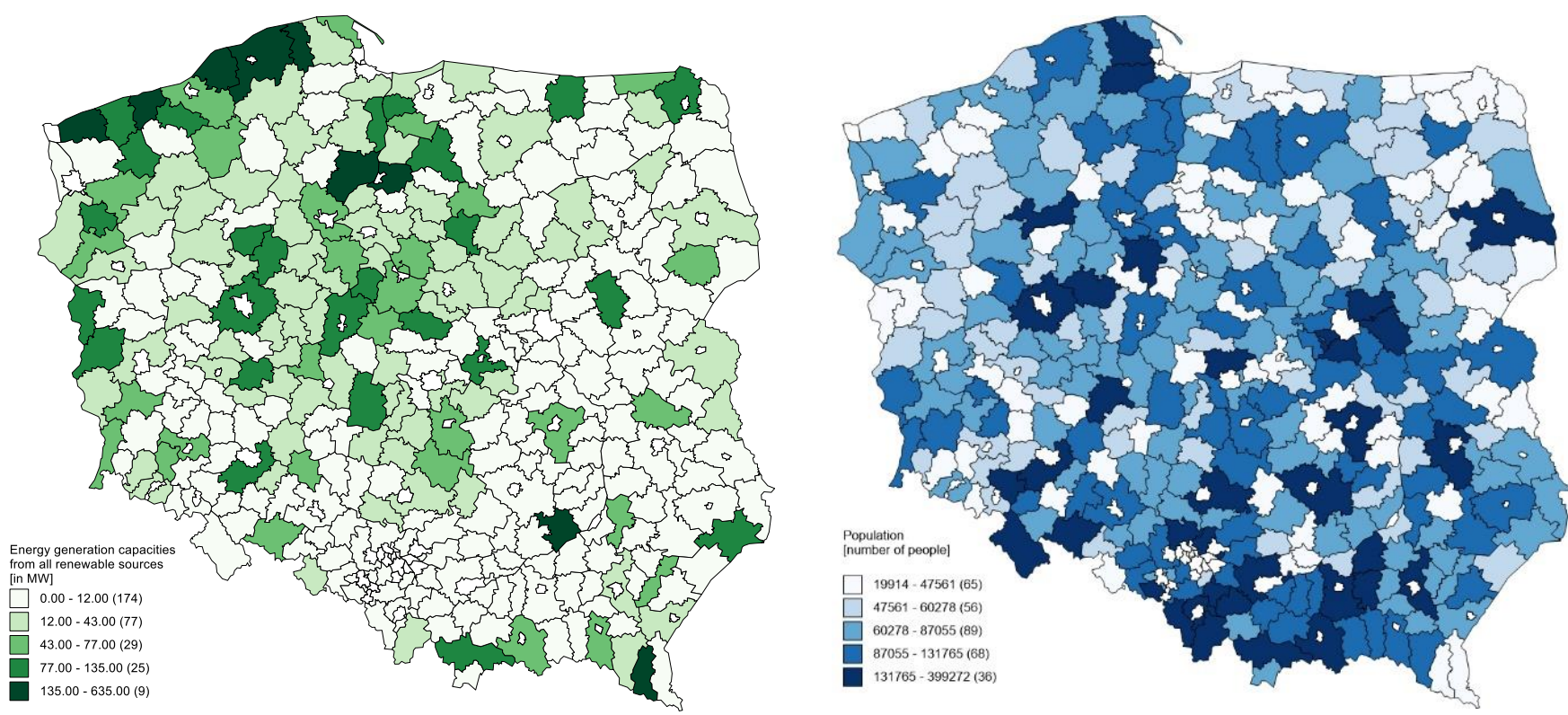

Figure 7. Renewable energy generation capacity of all installation types combined (left) and population (right) in districts of Poland in 2020. Source: own calculations and presentation.

The conducted analysis made it possible to identify four types of regions. Their spatial arrangement across the country has a mosaic pattern (Figure 8). The most numerous are the energy periphery regions (Table 3), which can be described as problematic regions with low energy generation capacity, while also manifesting low population numbers. And as the research conducted in Poland shows [47], the low population is generally accompanied by overall low socio-economic development and deficiencies in infrastructure. This also concerns the energy network infrastructure, which hinders and sometimes even blocks possibility for the development of new energy sources. Low level and quality of internal factors (both traditionally understood as soft factors) are noted here. Districts of this type are characterized by a low level of key conditions essential for the development of innovation. This is referred to in the literature as organizational thinness [45]. The problem of the periphery regions is also the underdeveloped network and connections of specialized knowledge providers, such as universities and research organizations [48]. This type of region occurs numerously throughout the country, but is especially highly concentrated in the north-east and mid-west of Poland. In terms of demographic determinants, the situation in these areas can be assessed as a range from bad to average. They are characterized by a negative migration balance and outflow of local residents, as well as by struggle with the problems of ageing population. Residents in these regions are primarily employed in small-scale agriculture, and have lower average education degree compared to residents of other regions [47]. Compared to Poland in general, these areas are the least economically developed, and the phenomenon of energy poverty occurs to a high extent in these regions. 


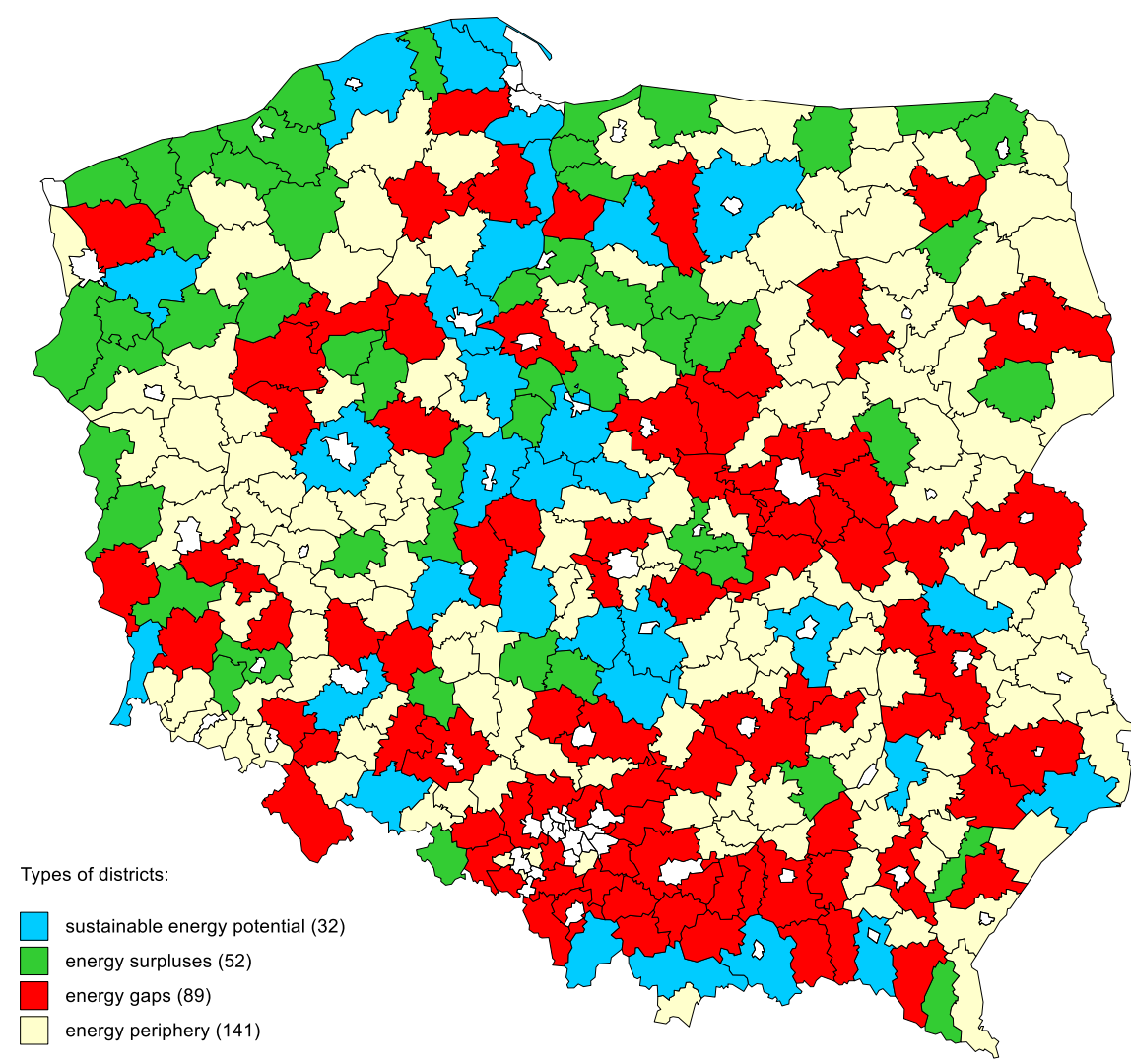

Figure 8. Spatial distribution of districts according to outlined types in 2020. Source: own calculations and presentation.

Table 3. Descriptive statistics for the analysis of districts according to their renewable energy generation type.

\begin{tabular}{|c|c|c|c|c|}
\hline \multirow[b]{2}{*}{ Parameters } & \multicolumn{4}{|c|}{ District/Region Types } \\
\hline & $\begin{array}{c}\text { Sustainable } \\
\text { Energy Potential }\end{array}$ & $\begin{array}{l}\text { Energy } \\
\text { Surpluses }\end{array}$ & $\begin{array}{l}\text { Energy } \\
\text { Gaps }\end{array}$ & $\begin{array}{c}\text { Energy } \\
\text { Periphery }\end{array}$ \\
\hline Valid & 32 & 52 & 89 & 141 \\
\hline Missing & 0 & 0 & 0 & 0 \\
\hline Mean & 75.844 & 91.047 & 7.799 & 7.658 \\
\hline Std. Error of Mean & 8.968 & 12.856 & 0.735 & 0.600 \\
\hline Median & 59.065 & 67.945 & 5.770 & 5.120 \\
\hline Mode * & 29.090 & 28.870 & 0.210 & 1.000 \\
\hline Std. Deviation & 50.728 & 92.704 & 6.929 & 7.122 \\
\hline Variance & 2573.356 & 8594.022 & 48.018 & 50.718 \\
\hline Skewness & 2.567 & 4.282 & 0.973 & 0.972 \\
\hline Std. Error of Skewness & 0.414 & 0.330 & 0.255 & 0.204 \\
\hline Kurtosis & 8.305 & 23.379 & 0.019 & -0.075 \\
\hline Std. Error of Kurtosis & 0.809 & 0.650 & 0.506 & 0.406 \\
\hline Range & 251.500 & 606.070 & 27.660 & 27.450 \\
\hline Minimum & 29.090 & 28.870 & 0.000 & 0.000 \\
\hline Maximum & 280.590 & 634.940 & 27.660 & 27.450 \\
\hline Sum & 2427.020 & 4734.460 & 694.090 & 1079.830 \\
\hline
\end{tabular}

Notes: * More than one mode exists, only the first is reported. Source: own calculations. 
The second most abundant type are the regions with energy gaps, which boasting a relatively high population are simultaneously characterized by low renewable energy generation capacities. These types of districts are located mainly in central and southern Poland. It should be noted that this type of region could transform rather quickly into the type with sustainable energy potential. This may be due to the existing population potential, since rural areas of this type are showing a positive demographic trend and are a migration destination [47], thus additionally stimulating their development. Areas of this type are often located near large cities that determine population development trend, but at the same time the low renewable energy generation capacity may indicate insufficient development of infrastructure networks (including energy networks). Unlike the periphery regions, they face the reverse problem of over-clustering because they are over-specialized in mature industries hit by decline [49]. This type of regions often has a highly developed and specialized system of knowledge generation and diffusion; however, their problem is too much focus on traditional industries and fields of technology (e.g., the region of Silesia) [50]. With regard to functioning networks of relations, a key feature of the old industrial regions is that they suffer from various forms of "lock-in" which significantly block the development potential and the possibilities of diffusion of innovation and knowledge. Such blockades are a consequence of overly rigid networks established between enterprises and the policy, and links between public and private entities, which hinder the process of industrial restructuring. However, these districts have a substantial positive potential for the development of prosumer energy, as the population with relatively higher income levels is more eager to install renewable energy installations [51]. Residents of areas described as regions with energy gaps are relatively well educated. These are people who maintain permanent contacts with the city-mainly by being employed there. It is possible that the environment these people dwell in, contacts with other educated and highly aware citizens positively affect their pro-environmental attitudes, which in turn leads to growing popularization of the prosumer model of energy generation in the areas of their primary residence.

Another type are the regions with energy surpluses. This type is characterized by low population potential and high energy generation potential—which is not used due to low population density. Spatially, such districts are located primarily in the north of the country-mainly in places where wind energy generation is being developed. Nevertheless, this type is also highly dispersed nationally. It can be seen that the surplus of energy results from the specificity of the sources located there. The energy generation capacities are not always located at the densely populated areas. The key task of such regions is to create energy transmission grids with regions of high energy needs. Financial resources and systemic solutions are needed so that these regions could flawlessly transmit energy. There is a lack of organizations that have commercialized this energy generation potential and there are no institutions connecting the regions.

The last and least numerous type are the regions with sustainable energy potential, which are characterized by high population numbers and high renewable energy generation capacities. Districts of this type are highly dispersed throughout the country. However, the sequence of communes running from Pomorskie to the central part of the country is quite characteristic. These regions are the least problematic because there is a balance between their needs and generation capacities. Yet political decisions, unfavorable for further development and the lack of continuation of the energy policy may pose a threat. Energy generation leaders in these regions block small producers, which makes it difficult to implement the idea of decentralized energy generation based on individual prosumers.

In the light of the differences in outlined types of regions an important issue is to understand possible implications that may have a systemic character and hinder the potential development of renewable energy generation. For this purpose a typology of systemic problems [52] has been combined with types of regions outlined in this study (Table 4). While the types of regions differ according to their renewable energy generation potentials, all four types may encounter mild or severe potential systemic problems, which 
might either slow down their positive development, or block possibilities of such. Again, an intensive transfer and wide diffusion of knowledge in this matter could serve as an important factor ensuring minimization of potential negative implications.

Table 4. Potential systemic problems in regions depending on their renewable energy generation.

\begin{tabular}{|c|c|}
\hline Region Types & $\begin{array}{l}\text { Potential Systemic Problems According to Selected Dimensions } \\
\text { (Based on Typology of Systemic Problems of [52]) }\end{array}$ \\
\hline & Capabilities/capacities: \\
\hline $\begin{array}{l}\text { Energy } \\
\text { periphery }\end{array}$ & $\begin{array}{l}\text { - } \quad \text { Lack of technological knowledge of policy makers and engineers, } \\
-\quad \text { Lack of ability of entrepreneurs to pack together, to formulate clear message, to lobby to the government, } \\
-\quad \text { Lack of users to formulate demand, } \\
\text { - } \quad \text { Lack of skilled staff. }\end{array}$ \\
\hline \multirow{8}{*}{$\begin{array}{l}\text { Energy } \\
\text { gaps }\end{array}$} & Knowledge infrastructure: \\
\hline & $\begin{array}{l}\text { - Wrong focus or no specific courses at universities and knowledge institutes, } \\
\text { - Gap/misalignment between knowledge produced at universities and what needed in practice. }\end{array}$ \\
\hline & Lack of legitimacy: \\
\hline & $\begin{array}{l}\text { - Different actors opposing change, } \\
-\quad \text { Individualistic entrepreneurs. }\end{array}$ \\
\hline & Too weak interactions: \\
\hline & $\begin{array}{l}-\quad \text { Individualistic entrepreneurs, } \\
-\quad \text { No networks, no platforms, } \\
-\quad \text { Lack of knowledge diffusion between actors, } \\
-\quad \text { Lack of attention for learning by doing. }\end{array}$ \\
\hline & Hard institutions: \\
\hline & $\begin{array}{l}\text { - "Misalignment" between policies on sector level such as agriculture, waste, and energy, and on } \\
\text { governmental levels, i.e., EU, national, regional level and other. }\end{array}$ \\
\hline \multicolumn{2}{|r|}{ Hard institutions: } \\
\hline $\begin{array}{l}\text { Energy } \\
\text { surpluses }\end{array}$ & $\begin{array}{l}\text { - "Stop and go policy": lack of continuity and long-term regulations; inconsistent policy and existing laws } \\
\text { and regulations, } \\
\text { _ "Attention shift": policy makers only support technologies if they contribute to the solving of a current } \\
\text { problem, } \\
\text { - "Valley of Death": lack of subsidies, feed-in tariffs, tax exemption, laws, emission regulations, venture } \\
\text { capital to move technology from experimental phase towards commercialization. }\end{array}$ \\
\hline \multirow{4}{*}{$\begin{array}{l}\text { Sustainable } \\
\text { energy } \\
\text { potential }\end{array}$} & Too strong interactions: \\
\hline & $\begin{array}{l}\text { - } \quad \text { Strong dependence on government action or dominant partners (incumbents), } \\
\text { - } \quad \text { Network allows no access to new entrants. }\end{array}$ \\
\hline & Market structures: \\
\hline & $\begin{array}{l}\text { - } \quad \text { Large-scale criteria, } \\
\text { - Incremental/near-to-market innovation, } \\
\text { - } \quad \text { Incumbents' dominance. }\end{array}$ \\
\hline
\end{tabular}

Source: own substantiation utilizing the typology of systemic problems from [52].

\section{Regional Innovation Systems, Social Networks and Knowledge Transfer}

The concept of regional innovation system (RIS) is popular among scientists of various disciplines as its theoretical framework responds to the needs of researching the phenomena and mechanisms related to the emergence of innovation and knowledge transfer [45]. The main idea behind the RIS is that the innovation efficiency in the economy depends on the innovative capabilities of enterprises and research institutions, and on how they interact with each other and public institutions [53]. The specificity of the concept lies in the fact that it shows overlapping dimensions, i.e., broadly understood institutional infrastructure and production system, and then explains the mechanisms of relations that arise between them based on established rules and regional policy. In this part of the study, authors search to answer what theoretical perspective the concept of RIS originates from, what are 
its main components and mechanisms, and whether there are different forms of RIS in the context of regional diversification of the periphery center.

The concept of RIS was created as a result of evolution of views on the functioning of the national innovation system (NIS), which was described in the works of Edquist [54], Lundvall [55], and Nelson [56]. It should be noted that it is quite difficult to identify the differences between NIS and RIS. The rationale for the emergence of the RIS from the general concept of NIS was that researchers wondered to what extent regions differ from one another in terms of their potential and processes that take place in the creation and absorption of innovation. It became the reason to propose a new concept, which to a greater extent takes into account the regional disparities of potentials for the creation of innovations. One of the first attempts to define and describe the concept of regional innovation systems can be found in Cooke et al. [15] who define the RIS as a system in which companies and other organizations are systematically engaged in interactive learning through an institutional environment characterized by embeddedness. In addition, Asheim and Isaksen [16] noted that a (regional) innovation system consists of a production structure (techno-economic structures) and institutional infrastructure (political-institutional structures).

In the definition of the concept of a regional innovation system, there are three important aspects that are key to its understanding. First is the expression "interactive learning", which means an interactive process by which knowledge is transferred, then combined and, as a result, constitutes a knowledge base as a shared resource of various entities cooperating in the system. Knowledge is the basic factor used not only in the process of creating innovation, but also in the process of absorption of innovation/technology and building cognitive, organizational and social closeness. Second, the term "environment" being an open territorial complex that includes principles, norms, values, and human and material resources. It is a set of territorial conditions which combined create a potential for the functioning of a system specific for a given area. The third aspect that definitely distinguishes the discussed concept is paying attention to social closeness. Economic relations are to some extent always embedded in a social context, while social ties or relations influence economic performance [57]. Social closeness is related to the term "embeddedness" which covers all economic and knowledge creation processes, and then its duplication in business environment and beyond. The process of learning and absorption of innovation is often based on trust, therefore social relations facilitate the exchange of tacit knowledge, which is by nature more difficult to communicate, exchange and trade through markets [58].

The concept of RIS assumes that innovation is a process in which enterprises use both internal and external resources of a material and institutional nature. It should be emphasized that the functioning of regional innovation systems depends not only on knowledge resources created by enterprises and institutions, but also on the strength and structure of relations, created networks, which are the platform of cooperation with the environment. Innovations do not arise in isolation and cannot thrive solely based on given enterprise's internal resources, but are rather a result of synergy of numerous factors and processes. The environment mentioned earlier can therefore be perceived as a network of entities and institutions that form the framework for innovative activity and interactive learning. Thus, the interaction between educational organizations, which can be defined in terms of knowledge and information flows, investment flows, networking and other partnerships, is the most important process driving the evolution and strengthening of RIS [53]. In conclusion, RIS is primarily a social system that involves systematic interactions between different groups of private and public sector institutions and individuals in order to increase localized learning opportunities in the region.

The innovation system requires defining its main components, i.e., institutions that play an important role in the innovation process. Lundvall [55] lists the basic elements of such system, which are: internal organization of enterprises, relations between enterprises, role of the public sector, institutional structure of the financial sector, research and development intensity, and research and development organizations. In general, the main 
elements encompassing RIS are enterprises, institutions, and the knowledge infrastructure and innovation policy.

An innovation-oriented policy is an important regulator of the processes that take place in the regional innovation systems. Its direction and scale of activities increase, among other things, the possibilities of learning and diffusion of knowledge. As practice shows, the optimal level to implement an innovation policy is one of a region, which was confirmed in the policy carried out by the European Commission [59,60]. The genesis of these policies dates back to the 1980s, when a group of OECD experts developed the concept of a dynamic approach to international competitiveness as an alternative to a static, cost-based view of the theory of international trade and competitiveness. The concept developed at that time assumes that international competitiveness can be achieved by promoting learning and innovation development in societies. Also in other dimensions, the approach to innovation systems represents an important theoretical and political progress. Identifying innovation as a key factor of economic growth emphasizes the role of interactive learning processes between multiple entities and organizations [61]. Such RIS policies aim to improve the interaction and collaboration between the knowledge infrastructure, companies and institutions. Moreover, these policies respond to individual and collective innovation needs. In other words, strategies are developed to support the endogenous institutional capacity of regions by encouraging the diffusion of technology on a regional scale [62]. Innovative policy tools typically include: managing the scientific knowledge base; providing financial incentives for innovation efforts, technology dissemination policies and initiatives; promoting programs and companies leading the implementation of new technologies; and the creation and maintenance of intangible assets and legal regulations that favor innovation and technology transfer.

RIS concept distinguishes four main internal mechanisms that explain the efficiency and success of the system, being the: interactive learning, knowledge generation, proximity, and social embeddedness. At a heart of the concepts of RIS and knowledge transfer is the concept of embeddedness, which is based on relationships and social networks and requires an understanding of the institutional and cultural context [55]. The concept of embedding appeared in social theory and works of James Coleman [63], which is the main propagator of the concept of social capital theory. According to this theory, the concept of rooting refers to resources embedded in the structure of social relations (networks). In social capital theory, the concept of "social embedding" describes a situation in which economic activities and behavior are related to or depend on non-economic institutions and activities such as culture, social networks, politics and religion [17]. The social structure is made up of connections with social networks, the key element of which is shaping of this rooting, as well as cohesion, integration and social support [64]. These are the features that are not subject to market rules, cannot be duplicated or sold, but are crucial for interactive learning [65]. From the perspective of diversifying development potentials, embedding occurs in regions where there is a significant concentration of enterprises and institutions, a high degree of shared social and cultural values, and various resources that can be used to generate new production and processes.

Within RIS, embedding concerns mainly the relationship between interactive and collective learning and the nature of knowledge exchange between enterprises and their institutional environment that supports innovation processes and knowledge transfer. It follows that networks of social and organizational relations constitute a key dimension of embeddedness. For shaping the policy of innovation and diffusion of knowledge, it is important to indicate which network structures are created under the RIS in regions with specific conditions influencing the development of innovations, as well as understanding who are the gatekeepers of knowledge, what are the mechanisms of information transfer and what are the abilities of the potential recipients to the knowledge.

In knowledge-based economies, innovation is considered to be the key driving force behind economic development [66]. Nowadays, they can rarely be developed by single entities or individuals. Their creation and success require the activation of the broadly 
understood innovative potential, located in the private sector of the economy, but also the one accumulated in the public and civic sector, so that as a result it is possible to engage the potential of creativity and innovation on a mass scale [67]. For this reason, intangible assets, in particular relational capital, play a special role.

This capital, apart from human capital (competences, education) and structural capital (structure/organization), is one of the components of intellectual capital [68]. It is defined as resources related to interpersonal relations, the ability to establish and maintain close and lasting relationships, building one's own social network [69]. Relational capital enables the creation of a network of contacts and long-term cooperation relations. The high level of this capital influences the connection of entities operating in the networks. It also affects the quality of information flow between network links and joint activities undertaken by all or only some of the entities [70].

These "social networks" contain two important components. The first is the network, which is essentially considered a structure formed by entities (primarily actors/entities) and their connections. The social nature of these connections, taking the form of interactions, relationships and ties, is the second component. Functioning in networks allows you to reach various resources through the exchange of knowledge. It enables the acquisition of external knowledge and combining it with individual/organizational and tacit knowledge. Nowadays, in a complex environment requiring a variety of reactions and stimuli, even large companies and organizations find it difficult to gather all competences and skills in one place [71]. An important element is also the interpenetration of different areas of knowledge. In addition, collaborative networking enables greater freedom and security through sharing experiences and sharing risks. Some researchers also argue that network structures can accelerate trust building in $\mathrm{R} \& \mathrm{D}$ cooperation, which typically requires mutual disclosure of knowledge related to competition [72,73].

On the one hand, networks enable the flow of knowledge based on direct relations, and on the other hand, they can contribute to the exchange of knowledge through indirect connections. In the case of indirect knowledge exchange, innovation brokers and gatekeepers of knowledge play an important role. Brokers are network actors that transfer knowledge between organizations that are not directly related [72]. They play the role of an information intermediary between information resources and people/organizations that need information. On the other hand, gatekeepers of knowledge absorb knowledge scattered on a global scale and introduce it to innovation processes-both at the regional and local level [66,71,74]. Their tasks, according to Wesley Cohen and Daniel Levinthal [75], are to monitor the external environment and translate technical information into a form that is understandable to local stakeholders. As a result, gatekeepers contribute to the popularization of new ideas and the transfer of new knowledge to the regional and local level [66]. Both brokers and gatekeepers act as knowledge repositories and contribute to the use of knowledge they derive from different contexts [76]. As a result, they do not so much control the flow of information, as influence it, among other by interpreting the message or giving it a specific meaning. In a sense, they decide which information will circulate and which will not.

\section{Discussion}

The study attempts to use the concept of regional innovation system to understand the dynamics of renewable energy generation development and the role and peculiarities of energy policy aimed at its development. Scarce attempts have been made so far to explore how the concept of RIS and social networks can support the diffusion of knowledge related to renewable energy sources. Moreover, the research conducted so far focuses mainly on regions with strong centrality features and well-developed economic and research infrastructure. Recent studies, however, suggest paying more attention to deficit and peripheral regions and their determinants for the creation and absorption of innovation and new technologies [77-79]. A particularly important area of research in which there is a knowledge gap are the problems of innovation systems occurring in regions with an 
energy deficit and peripheral regions with specific development characteristics, which can provide an appropriate framework for shaping energy policy focused on the development of renewable energy sources.

In order to understand the mechanisms underlying the appearance of regions characterized by energy gaps and energy peripherality, one should refer to the scientific paradigm related to the systemic nature of innovation [80]. This paradigm explains that the speed, direction and success of innovation processes are highly influenced by the environment, i.e., the regional innovation system in which innovations arise. Such a system as a complex structure of various institutions and their relations and principles of functioning, may encounter many emergency situations that hinder the processes taking place within it. Understanding these problems will help to better understand the occurrence of regional disproportions in the rate and level of investment for installations related to the production of renewable energy.

The main feature of large technological systems, including energy systems, is a strong interconnection with the economic system [81]. This dependence means that the transformation of the energy system will affect all elements of a sustainable economic system and requires an excessively high modernization effort, which many economies have not dealt with so far [82]. Literature review shows various theoretical and practical examples of problems related to the functioning of systems, such as: problems with the market structure, infrastructure problems, institutional problems, problems with interaction and problems with opportunities and local potential [52]. The systemic context allows, first of all, to identify directions of policy and public support, and to indicate areas with deficiencies in energy innovation and gaps in knowledge about them.

The new technology may face problems resulting from the market structure and competitive substitutes, which may be cheaper than the introduced innovations or have low utility when, for example, there are no externalities in the network. Moreover, when some actors dominate and control the market, the customer selection processes are limited [83]. Practical examples in Denmark show that in case of renewable energy generation installations, the small-scale wind energy generation technologies have been implemented successfully [84], as opposed to large-scale energy projects such as biomass [85], gasification and heat pumps [86], which in practice hampered the dissemination of the technology.

Infrastructural problems may concern equipping the region with physical facilities necessary for the functioning of society or enterprises in economic structures. These are, for example, electrical energy, natural gas transmission/distribution networks and communication networks such as high-speed ICT infrastructure and highways. Another dimension of infrastructural problems is equipping the region with a physical knowledge infrastructure, which includes highly specialized buildings (laboratories and research facilities) and equipment, as well as intangible infrastructure related to scientific and applied knowledge. The implementation of investments related to RES generation installations requires the transformation of large technical systems, such as the energy system. This is associated with high investment costs for the expansion of new infrastructure and coordination problems, and the entire process often requires government intervention [87].

Institutional problems relate to institutional mechanisms that may hinder innovation processes in the region. Institutions are the main constituent of innovation systems, and the institutional context defines this system and provides a structural framework. Formal institutions are consciously created and are characterized by clearly articulated and written rules of conduct, while informal institutions function as established rules of the game rooted in local social and cultural structures. Together, these two dimensions of institutions create the environment in which companies, knowledge institutions and the government itself are embedded [87]. In practice, institutional problems caused by instability in regulations and subsidy systems are often encountered. Once adopted, activities and support programs are withdrawn to be restarted after a few years. Such situations for micro-CHP, wind, PV, biomass and marine energy have been observed in the UK [88] or with solar collectors in Sweden [89]. Another observed phenomenon is the shift in political priorities with 
regard to the technology or its application context. An example of such activities is the implementation of solar cells in the Netherlands. A policy was adopted in the 1970s-1980s that focused on countries with the highest theoretical solar energy potential and developing countries as a priority, followed by a sudden increase in interest in PV technology in the 1990s, which due to climate change was also seen as an opportunity for the countries of North-Western Europe. The following years saw a change in policy and PV technology is no longer considered a viable option due to its high cost [90].

Another frequently mentioned problem in the functioning of institutions is the lack of coherent actions between different administrative levels in a given country. An example are biofuels and PVs in the Netherlands, both supported by provincial (regional) governments, while at the national level the government hinders the development and diffusion of these technologies [91,92]. Informal institutions, on the other hand, are responsible for the legitimacy of the implementation of new technologies and their social acceptance and observance through the prism of a given institution [93], in case of new technologies, obtaining legitimacy is often a slow and tedious process.

The functioning of formal and informal institutions often results in problems with network interaction. Actors of the innovation system, such as: enterprises, knowledge institutions, government-all interact with each other, including regarding product development and design, knowledge exchange and diffusion of new technologies. Interference and inefficiencies in the functioning of the network can be caused by either too strong or too weak interactions.

Network failure occurs when dominant gatekeepers and knowledge brokers fail to fulfill their role and consequently fail to provide the required knowledge. The network can also be too closed to external interactions, which means that actors are reluctant to leave the group or let new participants into it. Another situation concerns the imprisonment of relationships and the inability to develop the network, it results from the same costs of such changes as well as the possibility of establishing relationships with new partners. Network failure may also be caused by poor connectivity of network actors with new technologies, which prevents the process of learning, adaptation to new technological developments and innovations. Moreover, little involvement in cooperation in the system may lead to the lack of a common vision of technology development in the future, which in turn may hinder the coordination of research efforts and investments [87].

The company's abilities in the form of the lack of competences and resources to modernize and implement a new technology may also prove to be a significant problem [94,95]. The possibilities of searching for new solutions are significantly limited by the knowledge gaps of enterprises and the long cognitive and geographical distance, which is why they are often not aware of the existing opportunities and do not include innovation in their development vision [83].

Another issue are the interaction problems that affect the dissemination of knowledge in a multi-stakeholder regional system. Networking of different actors facilitates knowledge flows, accelerates technology development, reduces uncertainty and creates demand. Research in this area shows that weak or excessively strong connections and disturbances in the network are a mechanism blocking renewable energy generation technologies.

The case of Swedish producers of small biofuel boilers shows the lack of cooperation within the network and the weakness of the relationship [96]. There are only two or three producers of large biofuel boilers in Sweden, therefore the lack of cooperation may be due to the lack of potential partners. On the other hand, the weakness of relations and connectivity within the system may partially result from an information gap about other entities being potential partners in the region. Another issue is the considerable individualism of small companies, which means that these companies do not want to cooperate and share their knowledge with other companies. In addition, some companies, rooted for some time in local economic and social structures, are reluctant to new entities and create distance instead of building relationships. Summarizing, the case of Sweden shows that cooperation networks within the framework of energy generation technologies 
are characterized by poor connectivity and a lack of willingness to cooperate and share knowledge with other companies.

In terms of ways to assess the efficiency of regional innovation systems and their influence upon creation of innovations one of them is to take into account the number of patents. A research [97] was conducted within 194 countries to assess how different renewable energy support policies affect innovation in solar and wind energy generation technologies. This substantial work shows that a more comprehensive portfolio of renewable energy support policies increases the number of patents in the particular field, as well as there is a definite positive impact on patent activity, which is increasing significantly over time along with the growing duration of research programs and achievement of R\&D objectives.

A different approach to understanding of opportunities and constraints that are created by the development of renewable energy generation capacities is mentioned by van Zalk and Behrens [98] in the U.S.A. context. Namely, in their opinion the issue of land use in this regard is not in favor of renewable energy development, as "the surface area required for renewable energy systems is greater than that for non-renewable systems, exacerbating existing environmental policy challenges, from increasing land competition, to visual impacts". While this is certainly true and needs to be taken into account, the overall environmental benefits from decreased pollution are still prevailing.

\section{Conclusions}

The Polish energy sector is currently facing serious challenges, the currently defined directions of the state energy policy are to a large extent interdependent. With the clear goals to increase the share of renewable energy generation in the next decade intense transformations are needed to reach them, as in the past years its growth rates have been falling behind "the schedule". These can be achieved by simultaneous increase of renewable energy generation shares and by improving the energy efficiency. The later reduces the increase in demand for fuels and energy, contributing to increased energy security, as a result of reducing dependence on imports, and also works to improve the environmental impact of energy by reducing emissions. Similar effects are brought by the development of renewable energy generation, including the use of biofuels and non-pollutant technologies.

However, the sector also faces numerous challenges resulting from, inter alia, permanently high energy demand, inadequate level of development of fuel and energy production and transport infrastructure, high dependence on external supplies of natural gas, nearly total dependence on imported supply of crude oil, and environmental protection obligations, including climate change mitigation. These intensify the necessity to implement decisive measures to prevent deterioration of the economic situation of fuel and energy consumers. Therefore, in order to fully use the energy potential in Poland, it is necessary to use innovations and knowledge, especially expert knowledge. This is of exceptional importance for the energy sector, which operates in a complex legal, economic and technological environment.

In the energy sector nowadays, as in other sectors of economies, one of the conditions for functioning and development is the systemic use of knowledge to solve emerging problems, including creating and facilitating innovations. The fulfillment of this condition requires an incorporation of knowledge into management. The use of knowledge acquired at the local and regional level, within the company, as well as in contacts between various organizations obtained through networking activities can serve the process of gaining knowledge through the exchange of experiences, mutual evaluation of one's models and practices, exchange of views and ideas, and conducting joint experiments [18,70]. Network participants who are in contact with each other ignite discussions and generate new ideas, define stimulants and share experiences. A special role here is played by entities such as knowledge gatekeepers and brokers, which are responsible for providing practically useful knowledge to solve key problems of an organization (this type of knowledge can be defined as informal knowledge or unclassified knowledge), as well as information that contributes to the creation and implementation of innovative solutions. Gatekeepers and 
brokers often act as liaisons who influence the creation and connection of various sets of knowledge, both within the company and from external sources. These are people and entities with networking skills, with a high level of social and communication skills.

It is worth noting that while in highly developed, innovative areas both the networks themselves and the entities intermediating in acquiring are quite "dense", their shortage in peripheral areas may be another element hindering the development of innovation. In regional systems, the strive to increase innovation and related entrepreneurship contributes to changes in the functional structure of regions towards strongly developing regional centers and less growing peripheral areas [99]. However, it is commonly assumed that firms in peripheral regions benefit less from local knowledge transfer than firms located in agglomerations or industrial clusters [100]. This is due to the fact that the peripheral regions are characterized by a weaker supply of local knowledge transfer than the key regions. The literature indicates that companies and organizations from peripheral regions can be innovative to the extent that they are able to compensate for the missing possibilities of spreading and absorbing knowledge [101]. It is the collaboration in networks and with intermediaries for acquiring knowledge and skills that is a potential compensation mechanism, as they establish the organizational framework (organizational proximity) that enables interactive learning processes.

To conclude, the conducted analysis on the level of districts has revealed that the energy generation capacities in Poland are spatially unevenly distributed. Most of the surveyed districts are problematic areas which can be defined as energy periphery or energy gaps. These are areas that, regardless of the population and demographic situation, or the level of socio-economic development, are characterized by a low energy generation potential. Numerous densely populated areas are characterized by a scarcity of energy generation installations, thus also represent low energy generation potential. This may indicate the fact that the development of the network infrastructure-in this case, above all, the energy infrastructure-is not keeping up with the influx of people as well as social and population changes. Nevertheless, the investment potential in most of Poland is high. Thus, investment opportunities could be looked for in virtually every area of the market.

The authors focused on the characteristics of Polish regions regarding generation of renewable energy and its dependence on regional innovation systems and knowledge transfer. However, detailed definition of renewable energy generation development in light of local development conditions in various regions requires further study-including, among other, field research. It may be especially valuable to learn about non-economic factors, including relational capital and its role in the processes of energy generation knowledge/technology transfer and collective learning. Another important aspect that relates to regional innovation systems and renewable energy is the issue of existing policies for innovation and energy generation development. This would help to understand if their directions and implemented measures become catalysts for each other and if this accelerates the processes of transformation of the energy generation system achieving synergistic effect.

An interesting aspect for further analyzes could also be a research of the structure of energy generated from renewable sources, yet broken down into its types and specific sources. Investment chances could be analyzed separately, which are needed on every stage of product creation, in this case the generation and distribution of energy. Consequently, this may translate into energy security studies, whether on national or regional levels, either of which is a strategic issue for each country. Production and transmission of energy is an economic bloodstream, which, in addition to the transport system, determines the efficient functioning of the economy. Economic development of all countries depends on access to energy, which is why its sustainable development is so important.

Author Contributions: Conceptualization, P.Z., V.K. and D.Z.-G.; methodology, P.Z.; writingoriginal draft preparation, P.Z., V.K. and D.Z.-G.; writing-review and editing, P.Z., V.K. and D.Z.-G.; visualization, P.Z., V.K. and D.Z.-G.; supervision, P.Z. All authors have read and agreed to the published version of the manuscript. 
Funding: This research received no external funding.

Institutional Review Board Statement: Not applicable.

Informed Consent Statement: Not applicable.

Data Availability Statement: Not applicable.

Conflicts of Interest: The authors declare no conflict of interest.

\section{References}

1. International Monetary Fund. The Economics of Climate. Finance and Development 2019. Available online: https://www.imf. org/external/pubs/ft/fandd/2019/12/pdf/fd1219.pdf (accessed on 5 March 2021).

2. Lelieveld, J.; Klingmüller, K.; Pozzer, A.; Burnett, R.T.; Haines, A.; Ramanathan, V. Effects of fossil fuel and total anthropogenic emission removal on public health and climate. Proc. Natl. Acad. Sci. USA 2019, 116, 7192-7197. [CrossRef] [PubMed]

3. Shen, N.; Wang, Y.; Peng, H.; Hou, Z. Renewable energy green innovation, fossil energy consumption, and air pollution-spatial empirical analysis based on China. Sustainability 2020, 12, 6397. [CrossRef]

4. Vohra, K.; Vodonos, A.; Schwartz, J.; Marais, E.A.; Sulprizio, M.P.; Mickley, L.J. Global mortality from outdoor fine particle pollution generated by fossil fuel combustion: Results from GEOS-Chem. Environ. Res. 2021, 195, 110754. [CrossRef] [PubMed]

5. Meneganzin, A.; Pievani, T.; Caserini, S. Anthropogenic climate change as a monumental niche construction process: Background and philosophical aspects. Biol. Philos. 2020, 35. [CrossRef]

6. Burrell, A.L.; Evans, J.P.; De Kauwe, M.G. Anthropogenic climate change has driven over 5 million km2 of drylands towards desertification. Nat. Commun. 2020, 11, 3853. [CrossRef] [PubMed]

7. Taube, O.; Ranney, M.A.; Henn, L.; Kaiser, F.G. Increasing people's acceptance of anthropogenic climate change with scientific facts: Is mechanistic information more effective for environmentalists? J. Environ. Psychol. 2021, 73, 101549. [CrossRef]

8. European Commission. 2030 Climate \& Energy Framework. Available online: https://ec.europa.eu/clima/policies/strategies/ 2030_en (accessed on 12 April 2021).

9. Directive (EU) 2018/2001 of the European Parliament and of the Council of 11 December 2018 on the Promotion of the Use of Energy from Renewable Sources, 11 December 2018. Available online: http://data.europa.eu/eli/dir/2018/2001/oj (accessed on 28 March 2021).

10. European Commission. National Energy and Climate Plans (NECPs). Available online: https://ec.europa.eu/energy/topics/ energy-strategy/national-energy-climate-plans_en (accessed on 15 March 2021).

11. European Commission. Driving Forward the Green Transition and Promoting Economic Recovery through Integrated Energy and Climate Planning. Brussels, 17 September 2020. Available online: https:/ / eur-lex.europa.eu/legal-content/EN/TXT/?uri=COM: 2020:564:FIN (accessed on 2 April 2021).

12. Eurostat. Share of Energy from Renewable Sources (nrg_ind_ren). 2021. Available online: https://appsso.eurostat.ec.europa.eu/ nui/show.do?dataset=nrg_ind_ren\&lang=en (accessed on 3 April 2021).

13. European Commission. National Renewable Energy Action Plans 2020. Available online: https://ec.europa.eu/energy/topics/ renewable-energy/national-renewable-energy-action-plans-2020_en (accessed on 17 March 2021).

14. Kim, D. System Archetypes I: Diagnosing Systemic Issues and Designing High-Leverage Interventions. 2000. Available online: https:/ / thesystemsthinker.com/systems-archetypes-i-diagnosing-systemic-issues-and-designing-interventions (accessed on 28 April 2021).

15. Cooke, P.; Uranga, M.G.; Etxebarria, G. Regional systems of innovation: An evolutionary perspective. Environ. Plan. A Econ. Space 1998, 30, 1563-1584. [CrossRef]

16. Asheim, B.; Isaksen, A. Location, agglomeration and innovation: Towards regional innovation systems in Norway? Eur. Plan. Stud. 1997, 5, 299-330. [CrossRef]

17. Granovetter, M. Economic action and social structure: The problem of embeddedness. Am. J. Sociol. 1985, 91, 481-510. [CrossRef]

18. Allen, T.J. Managing the Flows of Technology: Technology Transfer and the Dissemination of Technological Information within the RED Organization; Mit Press: Cambridge, MA, USA, 1977.

19. O'Sullivan, M.; Overland, I.; Sandalow, D. The Geopolitics of Renewable Energy. Working Paper, June 2017. Available online: https:/ / energypolicy.columbia.edu/sites/default/files/CGEPTheGeopoliticsOfRenewables.pdf (accessed on 2 March 2021).

20. Statistics Poland. Energy from Renewable Sources in 2019; GUS: Warsaw, Poland, 2020.

21. Braczyk, H.J.; Cooke, P.N.; Heidenreich, M.; Krauss, G. Regional Innovation Systems: The Role of Governances in a Globalized World; Psychololy Press: London, UK, 1988.

22. Cooke, P. Regional innovation systems, clusters, and the knowledge economy. Ind. Corp. Chang. 2001, 10, 945-974. [CrossRef]

23. Cooke, P.; Uranga, M.G.; Etxebarria, G. Regional innovation systems: Institutional and organisational dimensions. Res. Policy 1997, 26, 475-491. [CrossRef]

24. Zito, A.R.; Burns, C.; Lenschow, A. The Future of European Union Environmental Politics and Policy; Routledge: London, UK, 2020.

25. Lu, Y.; Khan, Z.A.; Alvarez-Alvarado, M.S.; Zhang, Y.; Huang, Z.; Imran, M. A Critical review of sustainable energy policies for the promotion of renewable energy sources. Sustainability 2020, 12, 5078. [CrossRef] 
26. Sukhatme, S.P.; Nayak, J.K. Solar Energy: Principles of Thermal Collection and Storage; McGraw-Hill Education: Gautam Buddha Nagar, India, 2009.

27. Global Trends in Renewable Energy Investment. 2020. Available online: https://www.fs-unep-centre.org/wp-content/uploads/ 2020/06/GTR_2020.pdf (accessed on 11 May 2021).

28. Mathews, J.A. Developing Countries and the Renewable Energy Revolution. OECD Development Centre. Available online: https://www.oecd.org/dev/developing-countries-and-the-renewable-energy-revolution.htm (accessed on 12 May 2021).

29. Tomaszewski, K.; Sekściński, A. Odnawialne źródła energii w Polsce-Perspektywa lokalna i regionalna. Rynek Energii 2020, 4, 10-19.

30. Olszewski, M. O energetyce przyjaznej środowisku prawie wszystko. Warszawa Fund. Inst. Na Rzecz Ekorozw. 2012. Available online: https:/ / www.cire.pl/pliki/tematyczne/6/Leksykon_INE_DLA\%20DZIENNIKARZY.pdf (accessed on 15 March 2021).

31. Lehner, B.; Czisch, G.; Vassolo, S. The impact of global change on the hydropower potential of Europe: A model-based analysis. Energy Policy 2005, 33, 839-855. [CrossRef]

32. Varan, C.; Cretan, R. Place and the spatial politics of intergenerational remembrance of the Iron Gates displacements in Romania, 1966-1972. Area 2018, 50, 509-519. [CrossRef]

33. Cretan, R.; Vesalon, L. The political economy of hydropower in the communist space: Iron Gates revisited. Tijdschr. Voor Econ. En. Soc. Geogr. 2017, 108, 688-701. [CrossRef]

34. Sovacool, B.; Hancock, K. International political economy and renewable energy: Hydroelectric power and the resource curse. Int. Stud. Rev. 2018, 20, 615-632. [CrossRef]

35. Andonova, L.B. The Europeanization of environmental policy in central and eastern Europe. In The Europeanization of Central and Eastern Europe; Schimmelfennig, F., Sedelmeier, U., Eds.; Cornell University Press: New York NY, USA, 2005.

36. Batory, A. Why do anti-corruption laws fail in central eastern Europe? A target compliance perspective. Regul. Gov. 2012, 6, 66-82. [CrossRef]

37. Księżopolski, K.; Kotlewski, D.; Maśloch, G. Energetyka Odnawialna-Wyzwanie dla Krajów Europy Środkowo-Wschodniej; Raport; SGH Karpacz: Warsaw, Poland, 2020; pp. 129-165.

38. Min, R.M.; Gospodarki, W.D. Law of Poland on Renewable Sources of Energy (Ustawa z dnia 20 Lutego 2015 r. o Odnawialnych źódłach Energii); ISAP: Warsaw, Poland, 2015; p. 478.

39. Jenks, G.F. The data model concept in statistical mapping. Int. Yearb. Cartogr. 1967, 7, 186-190.

40. Energy Regulatory Office. Available online: https://www.ure.gov.pl/pl/oze/potencjal-krajowy-oze/8108,Instalacje-odnawialnychzrodel-energii-wg-stanu-na-dzien-31-grudnia-2019-r.html (accessed on 4 February 2021).

41. Energy Regulatory Office. Rejestr wytwórców ENERgii w Małej Instalacji (Register of Small Installation Energy Producers). Available online: https:/ /bip.ure.gov.pl/bip/rejestry-i-bazy/wytworcy-energii-w-male/2138, Rejestr-wytworcow-energii-wmalej-instalacji.html (accessed on 11 February 2021).

42. National Agricultural Support Center. Register of Small Installation Energy Producers. Available online: https://www.kowr.gov.pl (accessed on 2 February 2021).

43. National Agricultural Support Center. Rejestr Wytwórców Biogazu Rolniczego (Register of Agricultural Biogas Producers). Available online: https:/ / www.kowr.gov.pl/odnawialne-zrodla-energii/biogaz-rolniczy / wytworcy-biogazu-rolniczego/rejestrwytworcow-biogazu-rolniczego (accessed on 2 February 2021).

44. DWF. Quick Guide to the Polish Auction System for Renewables: Q\&A. 2020. Available online: http://psew.pl/en/wp-content/ uploads/sites/2/2020/06/QUICK-GUIDE-TO-THE-2020-POLISH-AUCTION-SYSTEM-FOR-RENEWABLES.pdf (accessed on 1 March 2021).

45. Tödtling, F.; Trippl, M. One size fits all?: Towards a differentiated regional innovation policy approach. Res. Policy 2005, 34, 1203-1219. [CrossRef]

46. Ministerstwo Aktywów Państwowych. Krajowy Plan na Energii i Klimatu na Lata 2021-2030: Założenia i Cele Oraz Polityki i Działania. 2019. Available online: https:/ / www.gov.pl/attachment/df8c4c37-808c-44ff-9278-676fb94add88 (accessed on 15 March 2021).

47. Stanny, M.; Rosner, A.; Komorowski, Ł. Monitoring Rozwoju Obszarów Wiejskich. Etap III. Struktury Społeczno-Gospodarcze, ich Przestrzenne Zróżnicowanie i Dynamika; Fundacja Europejski Fundusz Rozwoju Wsi PolskiejInstytut Rozwoju Wsi i Rolnictwa PAN: Warsaw, Poland, 2018.

48. Landabaso, M.; Mouton, B. Towards a Different Regional Innovation Policy: Eight Years of European Experience through the European Regional Development Fund Innovative Actions. Draft for Publication in Greenwood Publishing 2003, Brussels. Available online: http://www.fundacaofia.com.br/pgtusp/eventos/pag_simp2002/arquivos_simp2002/conferencia_final_ lessons.doc (accessed on 18 April 2021).

49. Tichy, G. Regionale Kompetenzzyklen-Zur Bedeutung von Produktlebenszyklus-und Clusteransätzen im regionalen Kontext. Z. Für Wirtsch. 2001, 45, 181-201. [CrossRef]

50. Kaufmann, A.; Todtling, F. Systems of innovation in traditional industrial regions: The case of Styria in a comparative perspective. Reg. Stud. 2000, 34, 29-40. [CrossRef]

51. Grabher, G. The weakness of strong ties; the lock-in of regional development in Ruhr area. In The Embedded Firm; on the Socioceonomics of Industrial Networks; Grabher, G., Ed.; Routledge: Oxfordshire, UK, 1993; pp. 255-277. 
52. Negro, S.O.; Alkemade, F.; Hekkert, M.P. Why does renewable energy diffuse so slowly? A review of innovation system problems. Renew. Sustain. Energy Rev. 2012, 16, 3836-3846. [CrossRef]

53. Doloreux, D. What we should know about regional systems of innovation. Technol. Soc. 2002, 24, 243-263. [CrossRef]

54. Edquist, C. Systems of Innovation: Technologies, Institutions and Organizations; Pinter: London, UK, 1997.

55. Lundvall, B.A. National Systems of Innovation: Towards a Theory of Innovation and Interactive Learning; Pinter: London, UK, 1992.

56. Nelson, R. National Systems of Innovation: A Comparative Study; Oxford University Press: New York, NY, USA, 1993.

57. Boschma, R. Proximity and innovation: A critical assessment. Reg. Stud. 2005, 39, 61-74. [CrossRef]

58. Maskell, P.; Malmberg, A. The competitiveness of firms and regions. 'Ubiquitification' and the importance of localized learning. Eur. Urban Reg. Stud. 1999, 6, 9-25. [CrossRef]

59. European Commission. National/Regional Innovation Strategies for Smart Specialisation. 2014. Available online: http: / / ec.europa.eu/regional_policy/sources/docgener/informat/2014/smart_specialisation_en.pdf (accessed on 29 April 2021).

60. European Commission. Regional Innovation Scoreboard. European Union: Brussels. 2017. Available online: https://ec.europa. eu/growth/industry/policy/innovation/regional_en (accessed on 1 April 2021).

61. Asheim, B.T. Smart specialisation, innovation policy and regional innovation systems: What about new path development in less innovative regions? Innov. Eur. J. Soc. Sci. Res. 2019, 32, 8-25. [CrossRef]

62. Hassink, R. Regional innovation policies compared. Urban Stud. 1993, 30, 1009-1024. [CrossRef]

63. Coleman, J.S. Social capital in the creation of human capital. Am. J. Sociol. 1988, 94, 95-120. [CrossRef]

64. Kwon, H.W. A social embeddedness perspective on turnover intention: The role of informal networks and social identity evidence from South Korea. Public Pers. Manag. 2017, 46, 263-287. [CrossRef]

65. Storper, M. The Regionalized World: Territorial Development in a Global Economy; Guilford Press: New York, NY, USA, 1997.

66. Kauffeld-Monz, M.; Fritsch, M. Who are the brokers of knowledge in regional systems of innovation? A multi-actor network analysis. Reg. Stud. 2013, 47, 669-685. [CrossRef]

67. Pike, S.; Roos, G.; Marr, B. Strategic management of intangible assets and value drivers in R\&D organizations. RD Manag. 2005, 35, 111-124. [CrossRef]

68. Lane, M.B.; Ross, H.; Dale, A.P. Social impact research: Integrating the technical, political and planning paradigms. Hum. Organ. 1997, 56, 302-310. [CrossRef]

69. Schrader, S. Informal technological transfer between firms: Cooperation through information trading. Res. Policy 1991, 20, 153-170. [CrossRef]

70. Morrison, A. Gatekeepers of knowledge within industrial districts: Who they are, how they interact. Reg. Stud. 2008, 42, 817-835 [CrossRef]

71. Fritsch, M.; Kauffeld-Monz, M. The impact of network structure on knowledge transfer: An application of social network analysis in the context of regional innovation networks. Ann. Reg. Sci. 2010, 44, 21. [CrossRef]

72. Nooteboom, B. Problems and solutions in knowledge transfer. In Cooperation, Networks and Institutions in Regional Innovation Systems; Fornahl, D., Brenner, T., Eds.; Edward Elgar Publishing: Cheltenham, UK, 2003; p. 384.

73. Das, T.K.; Teng, B.S. Trust, control and risk in strategic alliances: An integrated framework. Organ. Stud. 2001, 22, 251-283. [CrossRef]

74. Bathelt, H.; Malmberg, A.; Maskell, P. Clusters and knowledge: Local buzz, global pipelines and the process of knowledge creation. Prog. Hum. Geogr. 2004, 28, 31-56. [CrossRef]

75. Cohen, W.M.; Levinthal, D.A. Absorptive capacity: A new perspective on learning and innovation. Adm. Sci. Q. 1990, 128-152. [CrossRef]

76. Hargadon, A.; Sutton, R.I. Technology brokering and innovation in a product development firm. Adm. Sci. Q. 1997, 42, 716-749. [CrossRef]

77. Virkkala, S. Innovation and networking in peripheral areas-A case study of emergence and change in rural manufacturing. Eur. Plan. Stud. 2007, 15, 511-529. [CrossRef]

78. Fitjar, R.D.; Rodríguez-Pose, A. Innovating in the periphery: Firms, values and innovation in Southwest Norway. Eur. Plan. Stud. 2011, 19, 555-574. [CrossRef]

79. Petrov, A. Beyond Spillovers. Interrogating innovation and creativity in the peripheries. In Beyond Territory. Dynamic Geographies of Knowledge Creation, Diffusion, and Innovation; Bathelt, H., Feldman, M.P., Kogler, D., Eds.; Routledge: London, UK, 2011; pp. 149-167.

80. Smith, K. Innovation as a systemic phenomenon: Rethinking the role of policy. Enterp. Innov. Manag. Stud. 2000, 1, 73-102. [CrossRef]

81. Hughes, T.P. Networks of Power: Electrification in Western Society, 1880-1930; Johns Hopkins University Press: Baltimore, MD, USA, 1983.

82. Geels, F.; Hekkert, M.; Jacobsson, S. The dynamics of sustainable innovation journeys. Technol. Anal. Strateg. Manag. 2008, 20, 521-536. [CrossRef]

83. Jacobsson, S.; Johnson, A. The diffusion of renewable energy technology: An analytical framework and key issues for research. Energy Policy 2000, 28, 625-640. [CrossRef]

84. Raven, R.; Gregersen, K.H. Biogas plants in Denmark: Successes and setbacks. Renew. Sustain. Energy Rev. 2007, 11, 116-132. [CrossRef] 
85. Negro, S.O.; Suurs, R.A.A.; Hekkert, M.P. The bumpy road of biomass gasification in the Netherlands: Explaining the rise and fall of an emerging innovation system. Technol. Forecast. Soc. Chang. 2008, 75, 57-77. [CrossRef]

86. Raven, R.; Verbong, G.P.J. Ruling out innovations-Technological regimes, rules and failures: The cases of heat pump power generation and bio-gas production in The Netherlands. Innov. Manag. Policy Pract. 2004, 6, 178-198. [CrossRef]

87. Woolthuis, K.W.; Lankhuizen, M.; Gilsing, V. A system failure framework for innovation policy design. Technovation 2005, 25, 609-619. [CrossRef]

88. Foxon, T.J.; Gross, R.; Chase, A.; Howes, J.; Arnall, A.; Anderson, D. UK innovation systems for new and renewable energy technologies: Drivers, barriers and systems failures. Energy Policy 2005, 33, 2123-2137. [CrossRef]

89. Jacobsson, S.; Bergek, A. Transforming the energy sector: The evolution of technological systems in renewable energy technology. Ind. Corp. Chang. 2004, 13, 815-849. [CrossRef]

90. Verbong, G.; Geels, F. The ongoing energy transition: Lessons from a sociotechnical, multi-level analysis of the Dutch electricity system (1960-2004). Energy Policy 2007, 35, 1025-1037. [CrossRef]

91. Suurs, R.A.A.; Hekkert, M.P. Cumulative causation in the formation of a technological innovation system: The case of biofuels in the Netherlands. Technol. Forecast. Soc. Chang. 2009, 76, 1003-1020. [CrossRef]

92. Negro, S.O.; Vasseur, V.; van Sark, W.G.J.H.M.; Hekkert, M.P. Solar eclipse-The rise and 'dusk' of the Dutch PV innovation system. Int. J. Technol. Policy Manag. 2012, 12, 135-157. [CrossRef]

93. Bergek, A.; Jacobsson, S.; Sanden, B. Key processes and policy challenges in the formation and early growth of a technologyspecific innovation system: Lessons from the field of renewable energy. In Proceedings of the Workshop Understanding Processes in Sustainable Innovation Journeys, Utrecht, The Netherlands, 2-3 October 2006.

94. Afuah, A.N.; Utterback, J.M. Responding to structural industry changes: A technological evolution perspective. Ind. Corp. Chang. 1997, 6, 183-202. [CrossRef]

95. Anderson, P.; Tushman, M.L. Technological discontinuities and dominant designs: A cyclical model of technological change. Adm. Sci. Q. 1990, 35. [CrossRef]

96. Johnson, A.; Jacobsson, S. Inducement and blocking mechanisms in the development of a new industry: The case of renewable energy technology in Sweden. In Technology and the Market. Demand, Users and Innovation; Coombs, R., Green, K., Richards, A., Walsh, V., Eds.; Edwar Elgar Publishing Ltd.: Cheltenham, UK, 2000; pp. 89-111.

97. Hille, E.; Althammer, W.; Diederich, H. Environmental regulation and innovation in renewable energy technologies: Does the policy instrument matter? Technol. Forecast. Soc. Chang. 2020, 153, 119921. [CrossRef]

98. Van Zalk, J.; Behrens, P. The spatial extent of renewable and non-renewable power generation: A review and meta-analysis of power densities and their application in the US. Energy Policy 2018, 123, 83-91. [CrossRef]

99. Heffner, K.; Gibas, P. Obszary funkcjonalne ośrodków regionalnych w Polsce. In Zrozumieć Terytorium. Idea i Praktyka. Łódź; Nowakowska, A., Ed.; Uniwersytet Ekonomiczny w Katowicach: Katowice, Poland, 2013; pp. 217-238.

100. Grillitsh, M.; Nilsson, M. Innovation in peripheral regions: Do collaborations compensate for a lack of local knowledge spillovers? Ann. Reg. Sci. 2015, 54, 299-321. [CrossRef]

101. Lagendijk, A.; Lorentzen, A. Proximity, knowledge and innovation in peripheral regions. On the intersection between geographical and organizational proximity. Eur. Plan. Stud. 2007, 15, 457-466. [CrossRef] 